\title{
Ahrensi õlgadel. Ahrensi ortograafia ajalooliselt ja tänapäeval'
}

\author{
MATI HINT \\ Tallinna Ülikool
}

Ülevaade. Kuusalu pastor Eduard Ahrens (1803-1863) esitas oma eesti keele grammatikates 1843 ja 1853 nn uue kirjaviisi, mille eeskujuks oli soome keele ortograafia. Ahrensi taotluseks oli silbipikkuste adekvaatne edasiandmine. Soome keele eeskuju oli põhjendatud, sest soome ja eesti keele häälikusüsteemides, aga ka morfofonoloogias (astmevaheldus) on keeleajaloolistel põhjustel suur ühisosa. Kõige olulisem erinevus soome ja eesti keele häälikusüsteemides seisneb eesti keeles pikkade rõhuliste silpide prosoodias - selliseid silpe saab hääldada kahe erineva silbikvantiteediga

Kirjutis jätkab laiendatud kujul Eduard Ahrensi teemat, mida autor on korduvalt käsitlenud avalikes esinemistes:

1. "Ahrensi ortograafia ülistuseks." Eduard Ahrensi juubelikoosolekul (Ahrens 200) Emakeele Seltsis 29. aprillil 2003 peetud ettekanne; Mari Tarandile antud intervjuu samal koosolekul oli Vikerraadios ja Klassikaraadios "Keelekõrva" saates 3. mail 2003.

2. "Ahrensi ortograafia on eesti identiteedi oluline koostisosa." Ettekanne 30. märtsil 2015 Eduard Ahrensile pühendatud keelekonverentsil "Kummardus Ahrensile". Konverents toimus Teaduste Akadeemia saalis Tallinnas Kohtu t 6 ning selle korraldasid Kuusalu Laurentsiuse Selts, Emakeele Selts, Tartu Ülikool ja Eesti Keele Instituut.

3. "Eesti keele ortograafia ei vaja oma kaht põhireeglit." Ettekanne Kuusalus Eduard Ahrensi ausamba avamise konverentsil 10. augustil 2017. Konverentsi korraldasid Kuusalu Laurentsiuse Selts, Emakeele Selts, Õpetatud Eesti Selts ja Eesti Keele Instituut. 
(nn II ja III välde), millega ei kaasne silpide segmentaalkoostise muutust. Ahrensi ortograafia seda eesti keele prosoodilist eriarengut (soome keelega võrreldes) ei kajasta. Väga väikeste muudatustega on Ahrensi ortograafia teeninud eesti rahvast ja kultuuri 1870-ndatest aastatest alates.

Ajavahemikus 1840-1875 pandi eesti keele uurimisele üldkeeleteaduslikult tugev alus (Fr. R. Faehlmann, Eduard Ahrens, Jakob Hurt, F. J. Wiedemann). Õnnetuseks sündis 1870-1880. aastatel eesti häälikusüsteemi teooria (Mihkel Veske 1879, seejärel K. A. Hermann 1884), mis tõlgendas silpide prosoodilist kvantiteeti segmentaalhäälikute kolme erineva kestustena (lühike, pikk, ülipikk) ning diftongide ja konsonantühendite kahe erineva kestusena (pikk ja ülipikk). Silbiprosoodiat tôlgendati segmentaalselt. Selline vaade jäi valitsema umbes sajaks aastaks. Ahrensi ortograafia tõlgendati ümber, määrates hälilkud lühikeseks, pikaks või ülipikaks. Kogu eesti õigekirja õpetamine on tänapäevani allutatud kolme häälikuvälte valeteooriale, kuigi teoreetilistes käsitlustes hakkas Jakob Hurdale ja F. J. Wiedemannile toetuv silbiprosoodiline käsitlus tagasi tulema 1960. aastatest alates. Tänapäeval valitseb eesti häälikusüsteemi käsitlustes skisofreeniline olukord: deklaratiivselt on akadeemilistel tasanditel kolme häälikuvälte teooriast lahti öeldud, aga praktikas (aabitsad, õigekirjaõpetuse metoodika, mõnedki fonoloogilised tõlgendused) elab kolme häälikuvälte teooria edasi.

Võtmesõnad: hälikusüsteem; kolme häälikuvälte teooria; prosoodiline silbikvantiteet; ortograafia; astmevaheldus; eesti keel; soome keel

\section{Sissejuhatus: "Eesti keel on soome keele tütar"}

Eduard Ahrensi eesti keele grammatika ("Grammatik der Ehstnischen Sprache Revalschen Dialektes", 1843, 2. trükk 1853) esimene lause kõlab nii: "Eesti keel on soome keele tütar, sest viimane on esimese suhtes nagu algne keel tuletatud keele suhtes." (Kristiina Rossi tõlge kogumikus Ahrens 2003 [1853]: 83). See ongi nii, sest soome keel on säilitanud 
läänemereoome algkeelest päritud fonoloogilise ja morfofonoloogilise struktuuri palju algsemal ja järjekindlamal kujul kui eesti keel. Eesti keele foneetika ja morfofonoloogia (eriti astmevahelduse) uurimine oleks pääsenud paljudest vastuoludest ja ummikteedest, kui sellesse Ahrensi lausesse oleks tärkavas eesti rahvuslikus keeleteaduses suhtutud mõistmisega.

Ahrensi poeetilisse väitesse on hilisemate sugupõlvede keeleteadlased suhtunud erinevalt. Näiteks Kalevi Wiik on pooldanud seda vaadet, soovitades eesti keele õppimisel ja seletamisel toetuda soome keelele; Wiik lähtub soome keele pikematest morfoloogilistest vormidest, millest saab genereerida eesti keele lühemaid vorme (Wiik 1986; Wiik 1991: 33 jj, 99 jm). Eestis on Toomas Help pigem rõhutanud soome ja eesti keele erinevusi (Help 1988; Help 1989). Tuntud välismaistest soome ja eesti keele uurijatest on Robert T. Harms pidanud õigemaks käsitleda eesti keelt soome keelest sõltumatult (Velliste 1978). Siiski on paljud välismaised keeleteadlased ning eesti keele ja kultuuri huvilised eesti keele juurde jõudnud Soome ja soome keele kaudu; okupatsiooni poolsajandil oligi see peaaegu ainus võimalus. Eesti iseseisvuse oludes on situatsioon teine.

Paljudes häälikusüsteemi ja grammatika sõlmpunktides on eesti ja soome keele erinevusi lihtsam kirjeldada, transformeerides eesti vormid soome vormidest, mitte vastupidi (lõpukadu, sisekadu, prosoodia erinevus). Selle põhjuseks on keeleteaduse teoorias üldtunnustatud tõsiasi, et tänapäeva grammatika reeglid (eeskätt morfofonoloogilised vaheldused, näiteks sõnatüve astmete vaheldumine või lõpukadu nominatiivis *laulu > laul) kajastavad keeleajaloos toimunud hälikumuutusi. Kus soome keele vormid on pikemad (häälikuliselt täielikumad), seal on pikemast vormist lühema saamise seaduspärasusi võimalik reeglistada, vastupidine pole võimalik ( resp. on võimalik sõnaloenditena, mitte reeglitena). Seetõttu võibki soome keele grammatika kirjeldus (kui ja kus see on adekvaatne) anda lähteraamistiku eesti keele häälikusüsteemi ja morfoloogia kirjeldamiseks, muidugi vajalike kohandamistega. Süntaksis pole soome keele raamistik nii oluline, sest eesti (kirja)keele süntaks on tugevate alam- ja ülemsaksa keele mõjutustega. Soome ja eesti keele 
hälikusüsteemi, morfofonoloogia ja morfoloogia võrdlustes saaksid ühtlasi soome ja eesti keele erinevused selge väljenduse (juba Kettunen 1916: 10-33).

Järgnevate tabelite mõte ei ole terviksüsteemide võrdlemine, vaid põhimõtte illustreerimine. Tabelis 1 on esitatud soome keele häälikusüsteemi mitteammendav skeem.

TABEL 1. Soome keele häälikusüsteemi mitteammendav skeem

\begin{tabular}{|c|c|}
\hline $\begin{array}{l}\text { Silbituumadeks on lühikesed vokaalid - } \\
\text { V: } a, o, u, e, i, \ddot{a} \ldots- \\
\text { või pikad vokaalid, diftongid ja vokaali- } \\
\text { järjendid - VV: } a a, o o, a i, a u, o i, o u, o e \text {, } \\
\text { ue ... }\end{array}$ & $\begin{array}{l}\text { kala, koti, susi, elo, isä, hätä, veri, } \\
\text { Jumala, sydän, paksu, pelto, härkä ...; } \\
\text { paasi, kuusi, kaivo, kaula, koira, } \\
\text { laiva, koulu, koeta, luemme ... }\end{array}$ \\
\hline $\begin{array}{l}\text { Silbialgusteks on konsonandid - } \\
\text { C: } k, p, t, s, l, m, r \ldots \text {; } \\
\text { esisilbi ja 2. silbi piiril esinevad kaksik- } \\
\text { konsonandid ja konsonantühendid - } \\
\text { CC(C): } k k, p p, t t, s s, k s, p s, t s, s k, s t, m m \text {, } \\
l l, l m, l s, n s k \ldots\end{array}$ & $\begin{array}{l}\text { suku, koti, rapu, susi, kala, Jumala, } \\
\text { veri ...; } \\
\text { kukko, lippu, rotta, kissa, yksi, lapsi, } \\
\text { vitsi, laiska, kosto, kumma, kylmä, } \\
\text { tylsä, Ranska ... }\end{array}$ \\
\hline $\begin{array}{l}\text { 2) lahtisi ja kinniseid pikki rõhulisi esi- } \\
\text { silpe - (C)VV-CV..., (C)VC(C)-CV... }\end{array}$ & $\begin{array}{l}\text { kala, koti, susi, elo, isä, hätä, suku, } \\
\text { koti, susi, kala, Jumala, veri ...; } \\
\text { paasi, kuusi, kaivo, kaula, koira, } \\
\text { laiva, koulu ...; lippu, rotta, kissa, } \\
\text { yksi, lapsi, kylmä, Ranska ... }\end{array}$ \\
\hline \multicolumn{2}{|c|}{ Astmevaheldus morfofonoloogia osana kuulub morfoloogia sissejuhatusse } \\
\hline \multicolumn{2}{|c|}{ Mõlemad algupärase astmevahelduse liigid esinevad suhteliselt järjekindlalt: } \\
\hline 1) klusiilide $p, t, k$ ja $s$-i astmevaheldus; & $\begin{array}{l}\text { sika : sian, luku : luvun, siipi : siiven, } \\
\text { pelto : pellon, kynsi : kynnen, vesi : } \\
\text { veden ...; }\end{array}$ \\
\hline $\begin{array}{l}\text { 2) geminaatklusiilide astmevaheldus } \\
\text { nii lühikese kui ka pika silbituuma järel } \\
\text { (resp. silbi sonoorse osa järel) }\end{array}$ & $\begin{array}{l}\text { kukko : kukon, loppu : lopun; } \\
\text { saattaa : saatan, paikka : paikan, } \\
\text { aitta : aitan, palkka : palkan, kirppu : } \\
\text { kirpun ... }\end{array}$ \\
\hline
\end{tabular}


Põhilises samasugusena on Ahrens esitanud eesti keele hälikusüsteemi (ja selle pinnalt ortograafia) ning morfoloogia; astmevahelduse (mutatsioonid) paigutab ta morfoloogia algusse.

Tänapäeval ütleme, et astmevaheldus on nii soome kui ka eesti keeles morfofonoloogia kõige ulatuslikum ja tähtsam osa, mis kindlasti ei kuulu foneetikasse. Seda mõistis juba Faehlmann, kes flektiivsete tüvemuutuste liigitamisel selgelt eristas geminaatklusiilide vaheldumist (saak : sagi, auk : augo, ränk : ränga) ja laadivaheldust (märg : märja, kuub : kue jpt näited; süstemaatilised vead astmevahelduse käsitluses tulenevad Faehlmannil vanast kirjaviisist, mis näitasid tõeliste assimilatsioonijuhtude (wald: walla, kumb : kumma, kord : korra jpt näited) kõrval assimilatsioonina ka ortograafilist assimilatsiooni (lõhkuma : lõhhun, usk: usso, arg: arra jpt näited; vt Faehlmann 2002 [1843]: 37-49, 50-60).

Märkimist väärib, et Faehlmannil ja Ahrensil kuuluvad kõik geminaatklusiilide silbitüübid kokku: saak, auk, ränk järgivad ühtseid malle arusaam, mille hilisem häälikuvälte teooria lammutas, sest selles teoorias tuli määrata hälikute ja häälikuühendite välteid (aga -än- ei ole häälikuühend). Ahrensil võisid suunanäitajateks olla soome keel ja Faehlmann, viimane pidi silbist lähtuva keeleloogika najal sellise tüübimõistmiseni jõudma iseseisvalt. Et kõige üldisemaks astmevahelduse terminiks on Faehlmannil Abstufung (degradeerimine), see ütleb, et Faehlmann pidas astmevahelduse kirjeldamisel õigeks lähtumist tugevaastmelisest vormist, nagu ta enamasti ka ise toimis.

Tänapäevastele keeleteaduslikele teooriatele toetuvates soome keele grammatikates ei ole astmevaheldust foneetika osana käsitletud enam ammu. Väga põhjalik Fred Karlssoni "Suomen kielen äänne- ja muotorakenne" (1972) oleks oma struktuurilt sobinud vastava kirjelduse eeskujuks ka eesti keele häälikusüsteemi ja morfofonoloogia käsitlemisel. Aga ei, eesti keele kirjeldamisel tehti (ja tehakse suurel määral tänapäevani) otse vastupidi - keeleajalugu, tänapäevaseid üldkeeleteaduse teooriaid ja keele allsüsteemide loogikat ignoreeritakse ja leiutatakse oma teooriaid. Häälikuvälte sobitamine tänapäevaste foneemiteooriatega on andnud tulemuseks piinlikud vastuolud, olgu nende esitajateks ka 
TABEL 2. Eesti keele häälikusüsteemi sarnasus soome keelega

\begin{tabular}{|c|c|}
\hline $\begin{array}{l}\text { Silbituumadeks on lühikesed } \\
\text { vokaalid - V: a, o, u, e, i, ä ... - } \\
\text { või pikad vokaalid ja diftongid - VV: } \\
\text { aa, oo, uu ...; ai, au, oi, ei, õi, õu, üi ... } \\
\text { Laadivaheldusdiftongid esinevad } \\
\text { III-vältelistes silpides: }\end{array}$ & $\begin{array}{l}\text { kala, kodu, susi, elu, isa, häda, veri, } \\
\text { Jumal, paks, kops, härg ...; } \\
\text { paas, kool, kuus, hais, laul, kaev, koer, } \\
\text { sõir, oun, toit, eit, hüüe [üi]-difton- } \\
\text { giga ...; } \\
\text { saag : sae, nõgu : nõo, tegu : teo, käsi : } \\
\text { käe ... }\end{array}$ \\
\hline $\begin{array}{l}\text { Silbialgusteks on konsonandid - } \\
\text { C: b, d, g, s, m, l, r ... }\end{array}$ & $\begin{array}{l}\text { sugu, kodu, tõbi, susi, kala, Jumal, } \\
\text { veri ... (vrd sm suku, koti, susi ...), karbi, } \\
\text { välgu, külma ...; }\end{array}$ \\
\hline $\begin{array}{l}\text { Esisilbi ja 2. silbi piiril esinevad } \\
\text { kaksikkonsonandid ja konsonant- } \\
\text { ühendid - CC }(\mathrm{C}): \mathrm{k}(\mathrm{k}), \mathrm{p}(\mathrm{p}), \mathrm{t}(\mathrm{t}), \mathrm{ss} \\
\mathrm{ks}, \mathrm{ps}, \mathrm{ts}, \mathrm{mm}, \mathrm{ll}, \mathrm{lm}, \mathrm{nts}, \mathrm{mps}, \mathrm{rts} . .\end{array}$ & $\begin{array}{l}\text { kukke : kuke, lippu : lipu, rotti : roti, } \\
\text { kassi, üksi, lapse, külma, kintsu, } \\
\text { kompsu, sortsi ... }\end{array}$ \\
\hline $\begin{array}{l}\text { Silbiehituselt on oluline eristada } \\
\text { 1) lühikesi rõhulisi esisilpe - } \\
\text { (C)V-CV ...; }\end{array}$ & $\begin{array}{l}\text { kala, kodu, susi, elu, isa, häda, sugu, } \\
\text { Jumal, veri ...; }\end{array}$ \\
\hline $\begin{array}{l}\text { 2) lahtisi ja kinniseid pikki rõhulisi } \\
\text { esisilpe - (C)VV-CV ..., } \\
\text { (C) } \mathrm{V}(\mathrm{V}) \mathrm{C}(\mathrm{C})(\mathrm{C})-\mathrm{CV} \text {... }\end{array}$ & $\begin{array}{l}\text { maa, paas, kuus, } \operatorname{kaev}(u), \operatorname{kael}(a) \text {, } \\
\operatorname{koer}(\mathrm{a}), \operatorname{laev}(\mathrm{a}), \operatorname{kool}(\mathrm{i}) \text {...; lipp(u) : } \\
\text { lipu, rott(i) : roti, } \operatorname{kass}(\mathrm{i}), \operatorname{laps}(\mathrm{e}), \text { üksi, } \\
\text { külm(a), komps(u), vintske, piiska, } \\
\text { kausta ... }\end{array}$ \\
\hline $\begin{array}{r}\text { Esinevad mõlemad } \\
\text { astmevaheldus }\end{array}$ & \\
\hline $\begin{array}{l}\text { 1) klusiilide } b, d, g \text { ja } s \text {-i segmentaalne } \\
\text { astmevaheldus ei esine järjekindlalt; }\end{array}$ & $\begin{array}{l}\text { tegu : teo, siga : sea, lugu : loo, } \\
\text { tiib : tiiva, põld : põllu, kumb : } \\
\text { kumma, küüs : küüne, vesi : vee ...; aga } \\
\text { naba : naba, kodu : kodu, vaga : vaga, } \\
\text { mäda : mäda (vrd määndama) ...; }\end{array}$ \\
\hline $\begin{array}{l}\text { 2) geminaatklusiilide segmentaalne } \\
\text { astmevaheldus nii lühikese kui ka pika } \\
\text { silbituuma järel (resp. silbi sonoorse } \\
\text { osa järel) on suhteliselt järjekindel }\end{array}$ & $\begin{array}{l}\operatorname{kukk}(e) \text { : kuke, lõpp }(u) \text { : lõpu, saata : } \\
\text { saadan, paik(a) : paiga, ait(a) : aida, } \\
\text { palk(a) : palga, } \operatorname{kirp}(u): \operatorname{kirbu} . . .\end{array}$ \\
\hline $\begin{array}{r}\text { Eesti keele h } \\
\text { vältt }\end{array}$ & $\begin{array}{l}\text { sitle } \\
1875)\end{array}$ \\
\hline $\begin{array}{l}\text { Pika rõhulise esisilbi hääldus kahes } \\
\text { erinevas vältes, silbi segmentaalkoos- } \\
\text { tist muutmata, on eesti keeles uuen- } \\
\text { dus, mis soome keeles puudub }\end{array}$ & $\begin{array}{l}\text { kooli : 'kooli, kolli : ‘kolli, laulu : 'laulu, } \\
\text { metsa : 'metsa, kompsu : ‘kompsu, } \\
\text { laastu : ‘laastu, mõiste : 'mõiste ... }\end{array}$ \\
\hline
\end{tabular}


kuitahes tunnustatud nimed. Ainsad eesti keele grammatikad, mis pidasid sammu ajavaimuga ja keeleteaduse teooriaga (eeskätt foneemiteooriaga), ilmusid välismaal (Harms 1962; Tauli 1972). Nendes eesti keele grammatikates ei ole häälikutel kolme väldet ega liithäälikute (diftongide ja konsonantühendite) välteid ning astmevaheldus ei ole foneetika nähtus, vaid kuulub morfofonoloogiasse (Harms) või morfoloogiasse (Tauli).

Eesti keele häälikusüsteemi sarnasus soome keelega selgub tabelist 2 .

Selline on eesti keele häälikusüsteemi üks tänapäevane tõlgendus, mis läheb hästi kokku Eduard Ahrensi arusaamadega, nii nagu need väljenduvad tema ortograafias ja grammatikas.

Pikki vokaale ja kaksikkonsonante käsitatakse sellises vaates häälikuühendite (diftongide ja konsonantühendite) erijuhuna, kahe ühesuguse foneemi järjendina, mis ei anna pikki lisafoneeme, nii nagu ka diftonge ja konsonantühendeid ei ole võimalik käsitada ükskikfoneemidena. Sellise üldpildi kõrval postuleeritakse ka tänapäeval fonoloogilisi kontseptsioone, mille foneemide nomenklatuuris on nii lühikesed kui ka pikad vokaalid, nii lühikeed kui ka pikad konsonandid.

Ahrensi ortograafia (2003 [1853]: $\$ \$ 13-25,31-46)$ kajastab eestisoome sarnasust väga hästi (tabel 3).

Tegelikult käsitleb Ahrens vokaalide all ka $\tilde{o}$-d, aga ei anna talle oma kirjatähte (2003 [1853]: § 18, lk 94). Kui pikad vokaalid on tekkinud mutatsiooni tagajärjel, siis peab Ahrens neid mõnes kontekstis kahte silpi kuuluvaks: tegema ... te-e, vesi ... ve-e (vt $\$ 17,1 \mathrm{k}$ 93-94). Tänapäeval ei erine algupärased ja laadivaheldusest tekkinud pikad vokaalid enam karvavõrdki: vrd (maan)tee ja sina tee!

Ahrensil on $i$-lõpulised diftongid alati ühes silbis, ka siis, kui nad on tekkinud kontraktsiooni tagajärjel: tui, aita!, vrd tuvi ja avita ( $\$ 19$, lk 94-95), aga Ahrens toob näited ka kahte silpi kuuluvate diftongide kohta, mis niisiis polnud tema jaoks (resp. tollal) ehtsad diftongid: ea (rida : rea), oe (loetama, vrd lugema), öu (mööduma nõrk aste möub), iu (rius, vrd riid; see on üks väheseid Ahrensi ortograafiasüsteemi probleeme). Laadivaheldusdiftongidest peaks Ahrensi süsteemis 
TABEL 3. Eesti-soome sarnasuse kajastumine Ahrensi ortograafias

\begin{tabular}{|c|c|}
\hline $\begin{array}{l}\text { Lühikesed vokaalid }-a, e, i, o, u, \ddot{a}, \ddot{o} \text {, } \\
\ddot{u}(8) \text {; }\end{array}$ & $\begin{array}{l}\text { kala, lina, mure, kodu, tühi, täna, } \\
\text { sönum ...; }\end{array}$ \\
\hline $\begin{array}{l}\text { vokaalide topeldamine annab pikad } \\
\text { vokaalid, mida kirjutatakse kahe } \\
\text { tähega; }\end{array}$ & $\begin{array}{l}\text { maa, keel, kiidab, kool, kuulutaja, } \\
\text { kuusk, pääv, sääsk, pöörama, süü ...; }\end{array}$ \\
\hline $\begin{array}{l}\text { diftongid on alati pikad (neid on } \\
\text { Ahrensil 12) }\end{array}$ & $\begin{array}{l}\text { leib, laud, aeg, käe, koer, suits, köeb, } \\
\text { rea, öun ... }\end{array}$ \\
\hline $\begin{array}{l}\text { Lühikesed üksikkonsonandid - } \\
b, d, g, h, j, k, l, m, n, p, r, s, t, v \\
(14 ; \text { sõna alguses } p, t, k) ;\end{array}$ & agan, kosima, väli, maja ...; \\
\hline $\begin{array}{l}\text { pikad ja kaksikkonsonandid lühikese } \\
\text { vokaali järel; }\end{array}$ & $\begin{array}{l}\text { tal (st tald) : talla, nöm : nömme }{ }^{2} \text {, } \\
\text { varras, sülle ...; }\end{array}$ \\
\hline $\begin{array}{l}\text { klusiilid lühikese vokaali järel - } \\
k(k), p(p), t(t)\end{array}$ & $\begin{array}{l}\text { vak : vaka : vakka, käte : kätte, kot : } \\
\text { koti : kotti ...; }\end{array}$ \\
\hline klusiilid pika sonoorse silbiosa järel; & $\begin{array}{l}\text { pulka : pulga, köiki : köige, vaipa : } \\
\text { vaiba ...; }\end{array}$ \\
\hline $\begin{array}{l}\text { konsonantühendid - CC(C): } h t, h k, s k \text {, } \\
s t, k s, p s, t s, \operatorname{lm} \ldots ; m p s, r t s \ldots\end{array}$ & $\begin{array}{l}\text { jaht, välja, kaks, lahti, löhki, kustuma, } \\
\text { kapsad, mets, härg, külm; komps, } \\
\text { narts, körts ... }\end{array}$ \\
\hline $\begin{array}{c}\text { Astmevaheldus } \\
\text { tänapäevases eesti keeles }\end{array}$ & $\begin{array}{c}\begin{array}{c}\text { Ahrensil mutatsioonid } \\
\text { vormiópetuse alguses }\end{array} \\
\end{array}$ \\
\hline \multicolumn{2}{|c|}{ Esinevad mõlemad algupärase astmevahelduse liigid: } \\
\hline $\begin{array}{l}\text { 1) sulghäälikute } b, d, g \text { ja } s \text {-i segmen- } \\
\text { taalne astmevaheldus (laadivaheldus) } \\
\text { ei ole järjekindel; }\end{array}$ & $\begin{array}{l}\text { tegu : teu, tiib : tiiva, pöld : pöllu, } \\
\text { kumb: kumma, roog : roa, süsi : söe ...; } \\
\text { aga naba : naba, kodu : kodu, vaga : } \\
\text { vaga, mäda : mäda (vrd määndama) ...; }\end{array}$ \\
\hline $\begin{array}{l}\text { 2) geminaatklusiilide segmentaalne } \\
\text { astmevaheldus nii lühikese kui ka pika } \\
\text { silbituuma järel (resp. silbi sonoorse } \\
\text { osa järel) on suhteliselt järjekindel }\end{array}$ & $\begin{array}{l}\text { kukke : kuke, löppu : löpu; saata : } \\
\text { saadan, paik(a) : paiga, ait(a) : aida, } \\
\text { palk(a) : palga, } \operatorname{kirp(u)~:~kirbu~...~}\end{array}$ \\
\hline $\begin{array}{c}\text { Eesti keele hiline } \\
\text { prosoodiline vältevaheldus }\end{array}$ & $\begin{array}{c}\text { Seda Ahrens ei käsitle } \\
\text { (küll aga Wiedemann 1875) }\end{array}$ \\
\hline $\begin{array}{l}\text { Pika rõhulise esisilbi hääldus kahes } \\
\text { erinevas vältes, silbi segmentaalkoos- } \\
\text { tist muutmata, on eesti keeles uuendus, } \\
\text { mis soome keeles puudub }\end{array}$ & $\begin{array}{l}\text { kooli : 'kooli, kolli : 'kolli, } \\
\text { laulu : 'laulu, metsa : 'metsa, } \\
\text { kompsu : 'kompsu, laastu : 'laastu, } \\
\text { paiste : 'paiste ... }\end{array}$ \\
\hline
\end{tabular}

2 Selle ortograafiatüübi kommentaar on konsonantismi käsitluses (ptk 3.2). 
kahesilbiliseks klassifitseeruma ka ae (nt lagi : lae, saag : sae), kuid see diftong esines ka ühesilbilisena (aed, aeg).

Soome keele ortograafiast põhimõtteliselt erinev on Ahrensil ainult klusiilide käsitlus. Selle põhjuseks on nähtavasti tema soov säilitada (soome tähestikust erinevalt) eesti tähestikus ladina tähestiku leenisklusiilid $b, d, g$, mis tekitab ebasümmeetria lühikeste (naba, koda, tigu) ja pikkade silpide ortograafilisel defineerimisel, aga samas võimaldab pikkade silpide välteerinevust kirjas väljendada: vaka : vakka jne. Ka Ahrens ise mõistis, et klusiilid ei järgi tema ortograafias teiste pikkade kaksikkonsonantide orograafia malli: nöm : nömme, aga vak: vaka (vakka asemel; § 31, lk 102). Pika ja ülipika silbi (käte : kätte, koti : kotti) erinevust ning vajadust seda erinevust ortograafias väljendada mainib Ahrens soomepärase kirjaviisi ühe põhjendusena ainult klusiilide puhul ( $\$ 32$, $1 \mathrm{k}$ 103). Hilist vältevaheldust Ahrens ei käsitle ja tema ortograafia seda ei kajasta. Seda on kolme häälikuvälte teooria ajastul peetud Ahrensi ortograafia puuduseks, kuid on palju põhjusi pidada seda tema ortograafia vooruseks, sest hiline vältevaheldus on prosoodianähtus, mitte segmentaalfoneemide väldetega seotud nähtus, nagu seda tõlgendati häälikuvälte teoorias.

Erinevalt kolme hälikuvälte valeteooriast oli Ahrensile selge, et pika vokaali, diftongi ning lühikese vokaali + sonorandi järel käituvad klusiilid ühtmoodi (\$ 66, lk 128-129); toop, ait, pulk on juba klusiilide astmevahelduse tekkest alates kuulunud kokku nii foneetikas, astmevahelduses kui ka morfoloogias, ainult kolme häälikuvälte teooria on suutnud selle arusaamise asendada segadusega, liites selle varaseima astmevaheldusliigi hilise vältevaheldusega ning nõudes nendes silbitüüpides vokaalide ja konsonantide välte eraldi määramist. Isegi kui mõnes õpikus võeti ühte astmevaheldustüüpi kokku näiteks verbid taipama : taibata, vaatama : vaadata, märkama : märgata, on lähtekohaks ikkagi kolm häälikuväldet ning mainitud verbide astmevaheldust käsitati häälikute pikkuse vaheldusena $(b: p, d: t, g: k)$, mitte silbipikkuste vaheldusena. Sellise õpiku näiteks on Tartu ülikooli õppejõudude (Aino Valmet, Ellen Uuspõld, Ellen Turu) venekeelne "Учебник эстонского 
языка" - "Eesti keele õpik" (Valmet jt 1981: 103). Niisugused väikesed sammud silbipikkuste mõistmiseks ei muutnud üldist kaanonit.

Ometi oli õigem käsitlus juba rohkem kui sada aastat olemas. "On võimatu mitte märgata Ahrensi kirjaviisi paralleelsust soome keele ortograafiaga: soome kaappi - kauppi(as) - karppi ja eesti luupi - laupa lampi jne on sama põhimõtte avaldused ja teisiti see ei saagi olla, seletas ju E. Ahrens eesti keele ortograafiat soome keele põhjal." (Hint 2002: 24; vrd Ahrens 2003 [1853]: 102-103; vrd ka juba Faehlmann 2002 [1843]: 41, 53-54; mis Faehlmannile ja Ahrensile oli arusaadav, see tõlgendati nn "rahvuslikus keeleteaduses" ümber eriliseks eesti keeleõpetuseks.)

Oma grammatika hääldusjuhistes (ortoeepia osas, mis on ka ortograafia seletus), räägib Ahrens küll lühikestest ja pikkadest vokaalidest, kuid viimaseid kirjutab ta soome keele ortograafia eeskujul kahe tähega. Ortoeepiat-ortograafiat kirjeldades on Ahrensi põhiterminiks sil p, kusjuures kinniste silpide näideteks on halba, enne, mindi, tolmu; kahekordse konsonandiga enne on ühes näidete reas konsonantühenditega - tähtis oli, et silp oli kinnine, mitte et ühel juhul oli tegemist geminaatkonsonandiga ja teistel juhtudel konsonantühenditega (Ahrens 2003 [1853]: \$\$ 13-19, lk 92-95).

"See tähendab: Ahrensi ortograafia kujundati silpide ehitusele mõteldes, mitte "lihthäälikuid" kolmeks pikkusastmeks ja "liithäälikuid" kaheks pikkusastmeks analüüsides. Viimatine mõistestik on kõik mitukümmend aastat hilisem ning Ahrensi ortograafia omandamisel nähtavasti tarbetu või koguni eksitav ballast." (Hint 2002: 24)

\section{Ahrensi ortograafia raam}

\subsection{Eelkäijatest tuli ennast lahti mõtelda}

Oma grammatika sissejuhatuses käsitleb Ahrens eesti kirjakeele perioode. Ahrens liigitab eesti kirjakeele arengu 1) Stahlist Hornungini, 2) Hornungist Masinguni, ja 3) Masingust alates. Esimest iseloomustab Ahrens kui teadlikult rahvakeelekauge kirikukeele perioodi, kusjuures selle pioneerile Heinrich Stahlile (u 1600-1657) ei leia Ahrens ühtki 
vabandust: Ahrens on veendunud, et Stahl tundis eesti keelt hästi, aga pidas vajalikuks see tõmmata saksa liistule, et luua niimoodi kunstlik raamatukeel (Ahrens 2003 [1853]: \$3, lk 84). Heinrich Gösekeni (16121681) grammatika (1660) saab sama karmi hinnangu ja ainult Johann Gutslaffi (surn 1657) lõunaeesti keele grammatika (1648) leiab Ahrensi silmis armu. (See oleks intrigeeriv teema: kuivõrd huvitas Ahrensit lõunaeesti, st tartu keel.)

Johann Hornungit (1660-1715) hindab Ahrens kõrgelt, kuid ei pühenda kiidusõnu tema ortograafiareformile, vaid pigem Hornungi eesti keele oskusele, Uue Testamendi tõlkele ja mõningatele grammatika põhimõtetele. Ahrens hindab Hornungi käänamistüüpide eristamise põhimõtet: käänamistüübi määrab nominatiivi ja genitiivi (definitiivi ja relatiivi) suhe, mitte üksnes nominatiivi lõpptäht. See põhimõte on õige ka meie tänapäevaste teooriate ja teadmiste seisukohalt. Oma vormiõpetuses võtab Ahrens alusvormiks siiski nominatiivi, millele genitiivis (relatiivis) mehaaniliselt lisatakse tüvevokaal; see eeldab grammatika esitamist sõnaloendite abil ja teist teed sellise meetodi puhul üle ei jäägi. Sama meetodit kasutab poolteist sajandit hiljem ka Teaduste Akadeemia Eesti Keele Instituudi akadeemiline grammatika (EKG I 1995: 182-184 jm; Ahrensit selles suures grammatikaköites kahjuks ei mainita).

Piiblitõlge 1739 (eriti selle varasema kirikukeele traditsioone järgiv Vana Testamendi osa) kanoniseeris eesti kirikukeele, mis oligi ainus raamatukeel kuni Otto Wilhelm Masinguni (1763-1832). Keeleoskaja Masing kõigutas küll usku seniste grammatikareeglite paikapidavusse, aga uut süsteemi ei suutnud ta luua. See uus süsteem hakkas tekkima tõeliselt eesti keelt oskavate ja kirikukeele kaanoneid hüljata julgevate kirjameeste ja grammatikute töö tulemusena. Kõige positiivsemalt märgib Ahrens vara surnud dr Friedrich Robert Faehlmanni (1798-1850) ja Räpina pastorit Johann Friedrich Hellerit (1786-1849).

Niisugune on raamistik, kuhu paigutub Ahrensi enda grammatika. Selle ajaloolise raami joonistamisel ei heida Ahrens naljalt armu kellelegi, karmis sõnastuses deglorifitseerib ta kirikukeele ja -kirjanduse tunnustatud autoriteete. Pole ime, et Ahrensit eriti ei armastatud, 
sest tõde on valus kuulata, eriti kui see puudutab justkui revideerimisele mittekuuluvaid seisukohti ja aujärgi. Ahrensil tuli oma uus grammatika ja ortograafia süsteem luua oludes, kus eelkäijatele sai toetuda väga vähe.

\subsection{Misjon eesti keele heaks}

Eestikeelse kirikukirjanduse algetappide kohta on kasutatud misjonigrammatika mõistet. Misjonigrammatika mõistesse kuulub keele uurimine ja kirjakeele loomine kiriku misjonitegevuse tarbeks. Ka Ahrensi poolt Stahlile ja kirikukirjanduse esimesele või esimesele ja teisele ajajärgule antud iseloomustus sobib kokku misjonigrammatika mõistega eesmärgiks polnud eesti rahvakeelele võimalikult lähedase kirjutatud grammatika ja kirjakeelekasutuse loomine, vaid misjonis kasutatavate ja kirikukirjanduse keeltena tuntud keelte hulgast valitud eeskujudele - ladina ja saksa - võimalikult sarnase grammatika ja keelekasutuse loomine.

Kas Ahrens ka ise mahub misjonigrammatika mõiste alla? Jah ja ei, kuigi rohkem jah. Ahrens oli põhimõttekindel misjonär, aga misjonitöö vahendite suhtes oli ta teistsugusel seisukohal kui eesti kirikukeele (misjonikeele) varasemad autoriteedid. Ahrens ei pidanud õigeks kirikukeele saksapärastamist ja võõrastele eeskujudele toetumist. Kirikukeelt pidas Ahrens eesti keelele ülimalt tähtsaks. Oma grammatika sissejuhatuse lópetab ta veendumusega: puhas rahvakeel tõuseb eestlase silmis ausse alles siis, kui kirikuraamatud pöörduvad eestlase poole õiges eesti keeles. Kuni seda reformi ei sünni, on kõik eesti keele heaks tegutsemine viljatu.

Niisiis oli Ahrens ideoloogiliselt ikkagi misjonilingvistika esindaja, keeleteaduslikust vaatepunktist aga uue kvaliteediga grammatik, kes otsustavalt ütles lahti saksa ja ladina keele eeskujudest nii ortograafias kui ka grammatika kirjeldamisel. Ahrensit võib pidada misjonigrammatika ideoloogia lõpetajaks eesti grammatikakirjanduses, sest Wiedemanni grammatika (1875) ei olnud enam orienteeritud kirikukirjandusele, 
Karl August Hermann aga pühendas oma eestikeelse grammatika (1884) otsesõnu kallile armastatud Eesti rahvale. Kristiina Ross on Ahrensit nimetanud uue ajastu misjonilingvistiks: Ahrens oli nii keeletundja kui ka andekas grammatik, tema loobumine varasema ajajärgu võõrapärasest kirikukeelest oli põhimõtteline (Ross 2003).

\subsection{Ahrensi ortograafia alused}

Ahrensi grammatika järgib soome keele grammatika esitamise loogikat. Ahrens ise rõhutab nii põhimõttena kui ka näidetes ja loendites oma ortograafia soome eeskuju ning eesti sõnakujude tuletamise võimalikkust soome sõnadest (Ahrens 2003 [1853]: §57, lk 120).

Ahrensi ortograafia kohta üteldakse tavaliselt, et see on häälduspärane, kuid selline iseloomustus on liiga ähmane ja üldine. Ka vana kirjaviis oli häälduspärane, tuli ainult rakendada kindlaid silbi ehitust arvesse võtvaid reegleid, et selles kirjaviisis reeglikohaselt kirjutada või lugeda (viimane oli kahemõttelisem).

Ka Ahrensi kui ortograafi ja grammatiku mõtteviis toetub silbile. See vajab rõhutamist, sest häälduspärasuse all on nn rahvuslikus eesti keeleteaduses enamasti mõistetud häälikupikkuste edasiandmist häälikuväldete (vale)teooria tähenduses.

1. Ahrensi ortograafia ei püüa edasi anda häälikupikkusi, vaid tema taotluseks on silbipikkuste õigem märkimine; Ahrensi kirjaviis toetub silbi ehitusele palju rohkem, kui mitmed Ahrensi tõlgendajad on tahtnud näha. Ahrensil on vokaalid lühikesed või pikad, aga konsonandid ühekordsed (einfach) või kahekordsed (doppelt). Ahrens ei taotlenud vokaalide ja konsonantide sümmeetriat - see on õige seisukoht, milleni nn rahvuslik eesti keeleteadus pole jõudnud tänasekski.

2. Ahrensi ortograafias kirjutatakse segmentaalhäälikuid silbikonteksti arvestades; Ahrensi ortograafias polegi eesmärgiks ortograafias edasi anda ka prosoodilisi tunnuseid, nagu rõhk ja silbikvantiteet (nõrk või tugev aktsent ehk kerge või raske rõhk; viimast ta süstemaatiliselt võibolla ei tundnudki). 
Nendel taotlustel põhinebki Eduard Ahrensi loodud suurepärane ortograafia. Tavaarusaamades püsib äärmiselt visalt kolme häälikuvälte teooria valitsemisperioodil juurdunud väärettekujutus, et Ahrens mõistis eesti keele kordumatut ja ainuomast häälikulist ehitust ja andis eesti keele kolmele häälikuvältele ortograafilise väljenduse, aga tegi seda puudulikult. Selline ettekujutus on üdini vale. Sellest valearusaamast lähtub tänapäevani eesti ortograafia õpetamine ja reeglistamine. Kolme häälikuvälte teooria kerkis esile kirjaviisiväitluste ajal pärast Ahrensi surma ning selle eksliku teooria vormistas süstemaatiliselt alles Mihkel Veske "Eesti keele healte õpetus ja kirjutuse viis" (1879). Ahrens oli tolleks ajaks juba 16 aastat surnud.

Ahrensi loodud ortograafia on aja proovile vastu pidanud ja osutunud eesti keelele väga sobivaks. Ta ei ole nii pedantselt foneetiline, et nõuaks murdeti varieeruvate foneetiliste pisiseikade üleskirjutamist ja väljendamist ortograafilistes kaanonites. Kui Ahrens kirjeldab pikkade vokaalide diftongeeritud hääldust, siis viib see mõttele: kes tahab, võib ka tänapäeval kirjakeelt kõneldes madalaid ja keskkõrgeid pikki vokaale ( $a$ a $\ddot{a} \ddot{a}, o o, e e, \ddot{o})$ kergelt diftongeerida, mis siis sellest katki oleks. Enamus Ahrensi ortograafia parandamise ettepanekuid on lähtunud valeeeldustest: häälikuvältest ning taotlusest kajastada häälduse prosoodilisi erinevusi segmentaalsete tähtedena või tähejärjenditena. Ent Ahrensi ortograafia on põhimõtteliselt silbiline - prosoodilisi tunnuseid ei ortografeerita, ortografeeritakse silbi segmentaalne ehitus. Seetõttu lõhuksid taotlused ortograafias eristada hilistekkelist II ja III välte vastandumist läbiva süsteemina ja segmentaalsete vahenditega (tähtedena) selle ortograafia alused.

Ahrensist on järelpõlvedele jäetud mulje kui kiuslikust mehest, kellega oli raske asju ajada. Aga võib-olla ta polnudki nii halb mees, sest hoolimata oma riiust Õpetatud Eesti Seltsi ja Faehlmanniga, ei keela ta vähemalt pärast viimase surma lahkunule oma täit tunnustust (Ahrens 2003 [1853]: $\$ \$ 8,10-11,1 \mathrm{k} 87-90)$. Ehk on meie Ahrensi-pilti mõjutanud ka Arnold Kase üksikasjalik ja allikaterohke teos "Võitlus vana ja uue kirjaviis vahel..." (1958), milles on ajavaimule mõningast tollal 
kohustuslikku lõivu makstud ja pastor Ahrensi teeneid esitatud pigem tagasihoidlikus toonis kui ülistavalt. Faehlmann polnud Ahrensiga vaieldes ka sugugi süütu osapool: geniaalne eestlane Faehlmann agiteeris Ahrensi uue kirjaviisi vastu (Kask 1958: 48-51; Wiedemann 2011 [1875]: 54-57). Faehlmann oli küll käsitlenud tüvefleksiooni (astmevaheldust) morfoloogiliste vormide moodustamise vahendina (Faehlmann 2002 [1843]: 27-39, 50-60) ja toonud esile mitte-eestlastele tollal tihti käsitatamatu II ja III välte erinevuse (Wiedemanni arvates esimeste hulgas või esimesena; vt Wiedemann, samas lk 42; vrd Faehlmann 2002 [1852]: 235, 257-258), aga Ahrens ei püüdnudki neid võib-olla tallegi süsteemina mitte päris arusaadavaid vaheldusi ortograafiasse valada. Seda meie kõigi suureks õnneks, sest nii sündis mõistlik ortograafia, mis ei püüa kirjas kajastada silbi prosoodilisi tunnuseid. Ahrensi ja Faehlmanni tüli aga kuulub eesti kultuuriajaloo kurbseikade hulka.

\section{Ahrensi ortograafia alused tänapäevases vaates}

\subsection{Vokalism}

Ahrens ei kasuta silbituuma terminit, ta saab läbi vokaalide ja diftongide mõistetega. Kuid kuna ta toetub järjekindlalt silbile, silpide ehitusele ja silpide arvule sõnavormis ning märgib tihti ka silbipiiri, siis võib olla kindel, et tema käsitus silpide arvu ning silbituumade arvu vastavusest oli lähedal tänapäevasele.

Ahrensi silbituumade loendis on 8 vokaali, mis esinevad lühikestena ja pikkadena (pikkadena ainult esisilbis): $a, e, i, o, u, \ddot{a}, \ddot{o}, \ddot{u}$; diftonge on 12: ae, ai, au; ea, ei; iu; oe, oi; ui; äi; öi, öu; neist kuus (ae, ea, oe, öu, au, $i u$ ) esinevad ka kahesilbilistena - laadivahelduslike sõnade nõrga astme vormides (Ahrens 2003 [1853]: $\$ \$ 13-19$, lk 92-95). Ahrens toob näited selliste kahte silpi kuuluvate diftongide kohta, mis niisiis pole ehtsad diftongid: lae (lagi), kautama (kaduma), rea (rida), rius (riid), loetama (lugema), möub (mööduma-verbi murdevariant); i-lõpulised diftongid on alati ühesilbilised, ka siis, kui nad on tekkinud kontraktsiooni tagajärjel - tui (tuvi), aita (avita). Ahrensil kahte silbi kuuluv au on tänapäeval 
ao (kaduma $:$ kaotama) ning riid : rius = rii (j)us ei ole õige diftonginäide. Tänapäeval käsitatakse neid diftonge ühte silpi kuuluvatena (v.a rii-us), kuid licentia poetica nähtusena võivad nn hilisdiftongid värsis käibida ka kahe silbi eest:

so kä-e oma ohtjit kaknu,

so kässi lehmä, pini laknu... (Gustav Suits)

Kahvatades kustub eha-

ka-ob kaugustesse koit!

Närtsib suvi - langeb lumi -

langend surma õnnis loit? (Anna Haava; vt Hint 1971: 1577-1578)

Ahrens ei esita oma diftongide loendit diftongi järelkomponendi järgi liigitatult, nagu tänapäeval tavaks, vaid alfabeetilises järjestuses. Seda kindlamini võib väita, et Ahrensi käsituses olid pärisdiftongideks tänapäevases terminoloogias algupärased $i$ - ja $u$-lõpulised diftongid (ning algupärase pika ää diftongeerumisel tekkinud ea - pea, seadus; vt Ahrens 2003 [1853]: $\$ 33-34,1 \mathrm{k} 104$ ); e-lõpulistest diftongidest toob ta näiteid, milles $e$ on algupärasest $i$-st alanenud: koer, laenama, laev, aeg, poeg jt (samas). Ta pühendab palju tähelepanu pikkade vokaalide ja diftongide hääldusnüanssidele, kirjeldades nii silbipiire vokaalijärjendites kui ka pikkade vokaalide põhjaeestilist diftongeerunud hääldust (Ahrens 2003 [1853]: § 17-18, lk 93-94). Pika vokaali käsitamine kahe identse vokaali järjendina saaks teoreetilist tuge juba Ahrensilt: kui päiw > pääw (\$17, lk 93), siis on seda muutust kerge mõista, kui mõlemas variandis on silbituumas fonoloogiliselt kaks vokaali; sama saab ütelda vastupidise varieerumise kohta - kui pikk vokaal diftongeerub ( $p \ddot{a ̈ a ̈}>p e a$ ).

Ahrensi vokaaliortograafia mõne olulise nüansi paremaks mõistmiseks tuleb teha väike ajalooline ekskurss eesti keele silbituumade kujunemisse ja liigitusse. Tänapäeval jagatakse eesti keele esisilbi silbituumad sagedamini nii:

lühikesed vokaalid (9) - pikad vokaalid (9) - diftongid (27+) 
Fonoloogilistel, morfofonoloogilistel ja keeleajaloolistel kaalutlustel tuleks eelistada teistsugust liigitust:

\begin{tabular}{|c|c|c|}
\hline $\begin{array}{l}\text { lühikesed } \\
\text { vokaalid (9) }\end{array}$ & $\begin{array}{l}\text { algupäraselt pikad silbi- } \\
\text { tuumad: pikad vokaalid } \\
\text { ning algupärased } i \text { - ja } \\
u \text {-lõpulised diftongid ja } \\
\text { osa } e \text {-lõpulisi diftonge }\end{array}$ & $\begin{array}{l}\text { laadivahelduse tagajärjel tekki- } \\
\text { nud hilisdiftongid, mis algselt } \\
\text { kuulusid kahte silpi; Ahrensi } \\
\text { ja Wiedemanni järgi võisid } \\
\text { algselt kahte silpi kuuluda ka } \\
\text { hilistekkelised pikad vokaalid } \\
(\text { vesi }: \text { ve-e })\end{array}$ \\
\hline
\end{tabular}

Wiedemanni sõnaraamatu (1879 ja hilisemad trükid) puhul tuleb tähele panna, et kirjaviis wezi : wee ei pea tähendama ühte silpi kuuluvat pikka vokaali - ühte silpi kuuluva pika vokaali kirjutab ta ühe tähega: wēl 'noch', mitte nagu wezi : wee; sama moodi ei pea kirjaviis käzi : käe tähendama ühte silpi kuuluvat diftongi, ühte silpi kuuluva diftongi komponentvokaalid on tal ühendatud allkaarega (nt käima).

Diftongide arv on tänapäevases eesti keeles paari üksuse ulatuses vaieldav: näiteks euroga koos tuli võõras eu-diftong hälilikusüsteemi keskmele lähemale; diskuteerida võib pikkadest vokaalidest saadud diftongide algupärasteks või mittealgupärasteks liigitamise üle (hää pää > hea pea; maa > moa; $e$-lõpuliste diftongide liigitamine algupärasteks ja hilisdiftongideks võib mõnel üksikjuhul vajada seletamist jms). Põhilises on need liigitusklassid selgepiirilised, ka murretes, kus pikkade vokaalide diftongeerumine ning ka diftongide assimileerumine pikkadeks vokaalideks on ulatuslik.

Ajalooliselt, ka Ahrensil ja osalt veel Wiedemannilgi, on asjad teisiti: neil jagunevad ka pikad vokaalid algupärasteks ja hilisteks (tänapäevases terminoloogias); viimased, st laadivahelduse (mutatsiooni) tagajärjel tekkivad pikad vokaalid ja hilisdiftongid võisid jaguneda kahte silpi. Vokaalsete silbituumade liigitus on Ahrensi järgi selline (tabel 4): 
TABEL 4. Vokaalsete silbituumade liigitus Ahrensi järgi

\begin{tabular}{|c|c|c|c|c|}
\hline $\begin{array}{c}\text { Lühikesed } \\
\text { vokaalid }\end{array}$ & $\begin{array}{c}\text { Algu- } \\
\text { pärased pikad } \\
\text { vokaalid }\end{array}$ & $\begin{array}{c}\text { Algu- } \\
\text { pärased } \\
\text { diftongid }\end{array}$ & $\begin{array}{c}\text { Pikad hilisvokaalid } \\
\text { (Ahrens 2003 [1853]: } \\
\$ 17-19,1 \mathrm{k} 93-95)\end{array}$ & $\begin{array}{c}\text { Hilisdiftongid } \\
\text { (Ahrens, } \\
\text { samas) }\end{array}$ \\
\hline$a, e, u \ldots$ & $\begin{array}{c}a a, e e, \\
u u \ldots\end{array}$ & $\begin{array}{c}a i, e i, \\
a u \ldots\end{array}$ & $\begin{array}{c}\text { tegema }: \text { te-e, } \\
\text { wesi }: \text { we-e }\end{array}$ & $\begin{array}{c}\text { lagi }: \text { la-e, } \\
\text { rida }: \text { re-a }\end{array}$ \\
\hline
\end{tabular}

Kahte silpi jagunevate hilistekkeliste pikkade vokaalide ja diftongide esimese silbi vokaal on Ahrensil pikk. Seetõttu on tal klusiili kadu sõnades nagu 1) roog $(a), \operatorname{roog}(u), \operatorname{saag}(i), \operatorname{laug}(u), \operatorname{praad}(i), \operatorname{lood}(i)$ ühes tüübis klusiili kaoga sõnades nagu 2) löug(a), pöud(a), nöid(a), raud(a), $\operatorname{riid}(u)$ jpts (Ahrens 2003 [1853]: $\$ 63$, lk 127), sest tema jaoks olid mõlema sõnagrupi nõrga astme tüved kahesilbilised: ro-a, ro-o, sa-e ...; löu- $a$, nöi-a, ri-u ... Kuigi Ahrensi käsituses oli hilistekkelise (mutatsioonilise) vokaalijärjendi esimene vokaal pikk, kirjutas ta seda ühe tähega, andes reegli: teise vokaali ees kirjutatakse lahtise silbi pikk vokaal ühe tähega; niisiis toed 'Stützen', käed 'Hände', read 'Reihen', aga ka hoopis teise tüüpi kuuluvad rie 'Kleid', müa 'verkaufen' (Ahrens 2003 [1853]: \$ 14, lk 92).

Tänapäevaks on hilispikad vokaalid eristamatult liitunud algupäraste pikkade vokaalidega. Ahrensi ortograafia sobis niisuguse kontraktsiooni edasiandmiseks suurepäraselt. Hilisdiftongid jätkavad tänapäeva keeles omaette rühmana (esinevad peaaegu üksnes III-vältelistes silpides ja üldjuhul ei võta osa hilisest vältevaheldusest). Konservatiivsetes eesti murretes (nt kirderannikumurre) on vanemate inimeste kõnest registreeritud kahesilbilisi hilisdiftonge Ahrensist palju hilisemal ajal: tugi : tu-ed, nä-ost (Must 1987: 52, 134-135). Kuid kirjakeeles ja enamikus eesti murretest on ka hilisdiftongid põhiliselt tõmbunud ühte silpi kuuluvateks silbituumadeks ning foneetiliselt pole III-vältelises silbis vististi enam vahet algupärase ja hilise $e$-lõpulise diftongi vahel (nt 'laen : laenu: 'laenu ja 'laadima: 'laen või 'koer ja tugi : 'toel). Morfofonoloogia tänapäevasel reeglistamisel tuleb vältida lihtsustamist, mis näiteks roog : roo puhul võib nõrga astme vormi tuletada klusiili amputeerimise teel; keeleajaloos on laadivahelduse mehhanism roogu : roo ning rooga : 
roa puhul ühesugune 1) klusiili kadu, 2) esisilbi vokaali lühenemine ja 3) 2. silbi vokaali liitumine esisilbi vokaaliga pikaks silbituumaks, kusjuures kõrge tüvevokaal alaneb keskkõrgeks (saagi : sae, praadi : prae, poodi : poe, loogu : loo); tänapäevase keele morfofonoloogia kirjeldus võiks sellist teadmist respekteerida.

Nii Ahrens kui ka Wiedemann (1875) teevad vokalismi selle problemaatilise osa käsitlemisel märkusi, mille sisuks on mutatsiooniliste (astmevahelduslike) või kontraktsiooniliste pikkade vokaalide ja $i$-lõpuliste diftongide (viimaseid tekib teistegi morfofonoloogiliste protsesside järel - jää/ma : jä/i, maa : ma/i/d jt) kokkutõmbumine üheks silbituumaks: "Häälduses esinevad kaks ühesugust, elis[i]ooni tagajärjel kokku saanud vokaali peaaegu nagu üks pikk vokaal: nt paa (sõnast pada), ree (sõnast regi), lood ehk luud (sõnast lugu)." (Ahrens 2003 [1853] \$50-51, lk 117). Wiedemanni järgi juhtub see eeskätt sagadasemates sõnades ja juhtudel, mida me tänapäeval nimetame grammatiliste vormide leksikaliseerumiseks ( $\bar{e} s, \bar{e} l, s \bar{e} s$, sèst, kōs jne; Wiedemann 2001 [1875]: $\$ 19$, lk 109-110). Algupärased pikad vokaalid on avaldanud tugevat survet hilistekkeliste vokaalijärjendite kontraktsiooniks: raske oli juba Wiedemanni ajal eristada algupäraselt ühesilbilist wēl 'noch' ja tekkelooliselt kahesilbilist wesi : weel (Wiedemann, samas).

See tõi Ahrensi ortograafias kaasa ühe- ja kahekordse vokaali vaheldumise juhtudel nagu rie: riide, riu: riidu, lua: luиda, müa: müüma, aga selle näivvahelduse hilisem elimineerimine pole olnud kuigi raske. Ahrensi ortograafia oli loodud justkui kirjakeele tulevikku arvestades: kus hilistekkelised (mutatsioonilised) vokaalijärjendid tõmbusid kokku üheks pikaks silbituumaks, seal polnud vähimatki ortograafilist ümberkohendamist tarvis; kus nõrga astme tüved ja nendega häldustüübilt sarnased astmevahelduseta sõnad jäid kahesilbiliseks (sest neil on teise silbi alguses automaatne poolvokaal: siija, luuwa), seal oli hilisematel grammatikutel ja ortograafidel lihtne hakata esisilbi tõeliselt pikka vokaali kirjutama kahe tähega: riie: 'riide ja luиa: 'luиda, mü̈̈a: 'mü̈̈ma jne. Pikad vokaalid ja diftongid sulasid ortograafias kokku üheks pikkade silbituumade rühmaks: siig : siia ja määrsõna siia, laud: 
laua ja määrsõna kaua kirjutatakse ühe malli järgi, kuna nad häälduvad ühtmoodi. Juhtudel nagu lugu : loo on Ahrensi kahte silpi kuuluva vokaalijärjendi tõlgendamine ühte silpi kuuluvaks pikaks vokaaliks kulgenud enesestmõistetavalt.

Miks Ahrens ise ei läinud kahekordse vokaali kirjutamisel lõpuni? Võib oletada, et ta ei tahtnud juhtudel nagu käed, read, toed esimest pikka vokaali (seda see tema jaoks oli) kirjutada kahe tähega: käsi : kääed oleks olnud häiriv vaheldus ja ka soome keele kirjaviis ei pakkunud sellist eeskuju. Pikana tajutud või tõlgendatud vokaali ühe tähega kirjutamine tõmbas kaasa ka rie, lua ja müa tüübid, kus tüvevariantide ühesilbiliseks kokkutõmbumise eeldusi pole ning ka soome ortograafia kirjutab vokaali kahekordselt (kõrge vokaali järel ilma poolvokaalita: ruoka : ruuan, liika : liian, siika : siian, kuid vrd $j$-iga kirjutamist diftongilise silbituuma järel: äijä, Maija, Tuija). Wiedemann on kaasaegsena juba 1856. aastal laitnud rie ja lua tüüpi vormides pika vokaali kirjutamist ühe tähega (Kask 1958: 83), samuti Jakob Hurt (Hurt 2012 [1864]: 217).

Pikkade vokaalide foneemilisuse hindamisel andis oma lõpliku panuse eelmise sajandi lõpu silmapaistvaim eesti foneetik Arvo Eek, kes oma viimaseks suurtööks jäänud monograafia "Eesti keele foneetika. I" peatükis “Mitu vokaalfoneemi on eesti keeles?” (Eek 2008: 54-58) selgesõnaliselt ja väga otsustavalt loobus pikkade vokaalide foneemsusest, mida ta oli propageerinud aastakümneid: "Pika monoftongi ja diftongi bifoneemsuse [---] tunnustamine annab täiesti uue lähtealuse kestusega seotud nähtuste käsitlemiseks." Selle tsitaadi sees on ka viide Mati Hindi tööle "Eesti ortograafia (silbi)fonoloogiline põhi" (2002).

\subsection{Konsonantism}

Ahrens ei käsitlenud vokalismi ja konsonantismi sümmeetriliselt, sest tema keskendus silbile, silbistruktuuris aga on vokaalidel ja konsonantidel väga erinevad ülesanded. Et vokaalid on tal lühikesed või pikad, aga konsonandid ühekordsed (einfach) või kahekordsed (doppelt), siis kirjutab ta sõna ja silbi lõpus alati ühekordse konsonandi, mida pika vokaali 
AHRENSI ÕLGADEL

järel hääldatakse lühikesena ja lühikese vokaali järel pikana: loom, aga nöm, äm.

Niisugune kirjaviis toob kaasa näilise tüvevahelduse äm : ämma, kuid sellel ei puudu argumendid. Kuigi sellist ortograafiat kritiseeris juba Wiedemann (vt Kask 1958: 83), on tõenäone, et Wiedemanni kriitikat on hiljem interpreteeritud häälikuvälte teooria seisukohalt, justkui oleks Ahrens eksinud häälikute pikkuste süstemaatilisel edasiandmisel. See ei ole õige tõlgendus. Ahrens tahtis loobuda silbipikkuste moonutatud kirjutamisest vanas kirjaviisis (loom : loma) ning asendada selle silbipikkuste adekvaatse(ma) edasiandmisega soomepärases kirjaviisis. Ühe $m$-iga äm on ebajärjekindel häälikuvälte seisukohalt, kus seda $m$-i tõlgendatakse ülipika konsonandina; silbipikkuse edasiandmise seisukohalt on ühe, kahe või kolme $m$-iga äm, ämm, ämmm kõik võrdsed (Mihkel Veske kirjutas kolm konsonanti, lähtudes oma kolme häälikuvälte teooriast; vt Veske 1879: 27, 48 jm).

Fonoloogiateooria ajastul on Robert T. Harms eesti fonoloogia kirjeldamisel valinud Ahrensiga sarnase lahenduse: tüvevokaaliga varustatud alusvormile apokoobi rakendamise järel kaob lühikese vokaali järel vajadus konsonandi kahekordseks kirjutamiseks: $\operatorname{lin} n A>\operatorname{lin} n>\operatorname{lin}$ (Harms 1962: 43 jm). Ka Jakob Hurt nõustus selles silbitüübis Ahrensiga, kirjutades kas', sep, rop (Hurt 2012 [1864]: 217). Nagu Hurt sada aastat varem, nii ei lähtu ka Harms häälikuväldete teooriast (Harmsi eesti keele grammatika kirjandusloetelus Hurt puudub).

Klusiilide puhul on ühe- või kahekordse tähemärgi kirjutamist põgusalt arutlenud ka Ahrens, märkides, et fleksioonis tütar: tütre tuleks õieti kirjutada tüttre (= tüt-tre), aga seda ei loetaks teisiti kui tütre (Ahrens 2003 [1853]: § 31, lk 102). Sellest järeldubki kirjaviis tüt-, vak, sep, äm silbilõpulist konsonanti ei saa selles positsioonis hääldada kahekordselt (küll aga fonoloogia ajastul tõlgendada kahekordse foneemina).

Siiski on väga leidlik, et Ahrens klusiiliga silpides kasutab II ja III välte eristamiseks $b, d, g$ ja $p, t, k$ juba kinnistunud olemasolu eesti tähestikus: laut : lauda : lauta, sepa : seppa. Keeleajalugu teab, et geminaatklusiilide astmevaheldus (laata : laada, aita : aida, parti : pardi) on 
ajaliselt, häälikumuutusliku protsessina laadivahelduse paariline, mitte hilise vältevahelduse nähtus; viimane lihtsalt lisandus laadivahelduslike ja geminaatide vaheldusega sõnade vormidele. Üks eesti keeleteaduse suuri eksitusi on geminaatklusiilide astmevahelduse liigitamine kokku hilise prosoodilise vältevaheldusega.

Et Ahrensi ortograafia klusiiliga silbitüüpide astmevaheldust kajastab, selles võib näha ka soome keele kirjaviisi mõju: geminaatklusiilide segmentaalne astmevaheldus avaldub soome ortograafias geminaatklusiili ja üksikklusiili vaheldusena (paikka : paikan), Ahrensi eesti uues kirjaviisis aga tugeva $p, t, k$ ja nõrga $b, d, g$ vaheldusena: paika : paiga $=$ [paikka : păGa]. Niisiis oli Ahrens päris järjekindel: ta ortografeeris algupärased, soome ja eesti keelele ühised segmentaalselt avalduvad astmevahelduse liigid, millele ta leidis sobivad väljendused ka kirjatähtede ja ortograafiareeglite tasandil; hilistekkelise prosoodilise vältevahelduse kajastamist tema ortograafia ei taotlegi. Kes soovib, võib selles näha ka kirderannikumurde ja Ahrensi kodu-Kuusalu murraku foneetika mõju; kui see nii on, siis tuli eesti uuele kirjaviisile ainult kasuks, et Ahrensi-aegses Kuusalus hilise vältevahelduse II ja III välte erinevus puudus (nagu ka soome keeles).

Otstarbekas on seegi, et Ahrensil ei järgi klusiilid vak-sep-tüübi genitiivis äm-tüübi ortograafilist geminatsiooni: äm : ämma (kaks tähte), vaid kirjutatakse vak: vaka (üks täht) : vakka, sep : sepa : seppa (Ahrens 2003 [1853]: § 31, lk 102; §63, lk 125 jj). Nii pandi alus klusiilide erilisele ortograafiale, mis on Ahrensi konsonantide ortograafia süsteemis pigem erandlik kui reeglipärane. Hiljem pole seda kaugeltki alati mõistetud, vaid vastupidi, II ja III välte ortograafiline väljendamine vaka : vakka on võetud malliks, mida juba kirjaviisivaidluste ajal soovitati laiendada ka hilise vältevahelduse sõnatüüpidesse; hiljem taotles Mihkel Veske seda süsteemina (Veske 1879).

Probleemne ortograafia $\ddot{a} m(m)$ sai Ahrensi ortograafia revideerimisel hiljem lahenduse, mis lähtus häälikuvälte teooriast: III-välteline häälik kirjutatakse kahe tähega, kui tegemist ei ole häälikuühendiga (vastavuses eesti ortograafia nn teise põhireegliga). Kahe $\mathrm{mm}$-iga ämm 
(nagu ka vakk, sepp) vähendab ortograafia tasandil morfofonoloogilisi alternatsioone, seetõttu sobib see korrektsioon eesti ortograafiasse väga hästi ega aja Ahrensi ortograafia põhistruktuuri segamini. Tänapäevased fonoloogiateooriad (nt generatiivne fonoloogia) saavad vastuoludeta hakkama isegi ämmaga: kui fonoloogilise representatsiooni alusvormiks on * ämma, siis apokoobi järel geminaatse $m m$-i teine $m$ lihtsalt ei realiseeru sõnalõpulises positsioonis, alusvormi jääb ikka -mm-.

Vajadus Ahrensi ortograafiat põhimõtteliselt revideerida piirdub käsitletud juhtudega:

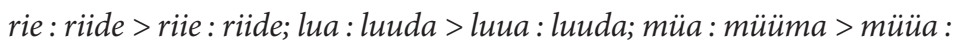
mü̈̈ma ning

äm : ämma > ämm : ämma ja sep : sepa : seppa > sepp : sepa : seppa.

Ahrensi ortograafia teistes hilisemates pisimuudatustes on nii õnnestunuid kui ka asjatuid. Kõige õnnestunum on selle ortograafia juurde jäämine kõiges põhilises.

Ahrens oli väga teadlik sellest, et ortograafia võib juhtida meid valesti tõlgendama vaheldusi, mille tegelik olemus on hoopis teistsugune. Näiteks juhib ta tähelepanu sellele, kuidas vanas kirjaviisis klusiili väljalangemise juhud muutuvad assimilatsioonideks: nahka : nahha, arga : arra; vastavalt muutuvad klusiili sisseviimise juhud dissimilatsioonideks: ehhe: ehte, puhhas: puhta (Ahrens 2003 [1853]: \$32, lk 102-103). Vana kirjaviisi pettepildist mõjutatud valetõlgendusi esitas süstemaatiliselt isegi Faehlmann, liigitades tõeliste assimilatsioonide (nt sild : silla) kõrval assimilatsioonideks ka klusiili kao juhud nagu puhkama : puhhata, uskuma : ussun jts, ning kaksikkonsonantide kaoks astme nõrgenemised nagu tubba: toa, mäggi: mäe jts (Faehlmann 2002 [1843]: 45-47, 54-58). Vanas kirjaviisis olid ka loom : loma ja keel : kelu : keelduma paratamatult ortograafiliste tüvevaheldustega. Sõnatüve variantide häälikuliste vahekordade moonutumine vanas kirjaviisis oli Ahensi silmis põhjendatult üks vana kirjaviisi suuri puudusi.

Ka mõni tänapäine pikkade konsonantfoneemide kontseptsioon moonutab sõnatüve variantide vahekorda. Eriti on see iseloomulik 
häälikuvälte teooriale, kus nii vokaalidele kui ka konsonantidele omistatakse kolm väldet: lühike, pikk, ülipikk. Kuid ka häälikuvältele (näiliselt) selja pööranud teooriates võidakse vokalismi ja konsonantismi näha sümmeetriliselt: kui vokalismis on foneemide nomenklatuuris eraldi lühikesed ja pikad vokaalid, siis olgu nii ka konsonantidega. See toob kaasa asjatuid teoreetilisi vastuolusid, näiteks silbi kinnisuse-lahtisuse ning silbipiiri defineerimisel silbipiirilise pika konsonantfoneemi korral Eesti Keele Instituudi "Eesti keele grammatika" I köites (EKG I 1995). Selles grammatikas läheb fonoloogilises transkriptsioonis kirja tasandil silbipiir pika konsonantfoneemi eest ning esisilp on fonoloogilise kirja tasandil näiliselt lahtine juhtudel nagu $k^{\prime} u \bar{m} a, k^{\prime} a \bar{n} a, m^{\prime} \ddot{a} \bar{s} u$ 'kumma, kanna, mässu' (II vältes; vt EKG I 1995: 108). Tegelikult tuleb selline kirjaviis varustada ümberdefineerimisega: "Kui pikk konsonant hääldub geminaadina, poolitab teda alati silbipiir, nt $t^{\prime} a m-m e, p^{\prime} i k-k a$, $k^{\prime} u l^{\prime} p-p i . .$. ( (samas, lk 111). Kahte silpi kuuluva silbipiirilise geminaadina hälduva konsonandi tõlgendamine ühe pika foneemina ei ole fonoloogia teoorias sugugi enesestmõistetav; eesti häälikusüsteemi fonoloogilises tõlgenduses on see pigem meelevaldne originaalitsemine.

Geminaatklusiilide astmevahelduse käsitlemine pikkade foneemide abil muudab astmevaheldusmudeli supletiivseks - vahelduses kinkima: kingin $=/ \mathrm{k}^{\prime}$ ink ima $: \mathrm{k}^{\prime}$ inkin/ asendatakse EKG I (1995: 151) tõlgenduses pikk foneem $/ \overline{\mathrm{k}} /$ lühikese foneemiga $/ \mathrm{k} /$, kuigi tegelik protsess nii hälikuajaloos kui ka tänapäevases morfofonoloogias on nõrgas astmes ühe konsonandi kadumine klusiilgeminaadist. Raske on leida põhjendust, miks geminaatklusiilide astmevahelduse käsitlus eesti keele grammatikas viiakse lahku sama nähtuse adekvaatsest kirjeldamisest soome keele morfofonoloogias.

Pikkade konsonantfoneemide tõlgendus on halb ka selle tõttu, et 2. silbi alguline konsonant ei mõjuta esisilbi pikkust; kui nüüd silbipiiril on pikk konsonantfoneem, siis on fonoloogiline mudel fonoloogilise kirja kajastuses ebaadekvaatne mitmekordselt: esisilbi pikkuse määramiseks tuleb 2. silbi alguline pikk konsonantfoneem jagada kahe silbi vaheliseks geminaadiks ning fonoloogilises kirjas lahtine esisilp liigitada 
kinniseks: /t'amel > t'am-me. Sellised keerdkäigud ignoreerivad keeleajalugu ja komplitseerivad asjatult morfofonoloogia kirjeldamist.

Pole ime, et Ahrensi ortograafia- ja ortoeepiakäsitlustes leidub seisukohti, millega tänapäeval ei saa nõustuda. Näiteks konsonantide palatalisatsiooni (dilutsiooni) peab ta teise silbi $i$ või $j$-i mõjuks esisilbi vokaalile (perekonnanimed nagu Kaints, Oit, Kaing võivad olla niisuguse taju kajastus); Ahrensi taotlus märkida velaarset nasaali $n g$-ga ei leidnud heakskiitu, sest selle järele polnud vajadust. Ahrens väidab, et eestlane ei ütle söber-tüüpi sõnu kunagi er-el-lópuga, vaid üksnes kui söbr või söbre; see lokalism taandus kiiresti. Need on pisiasjad suure õnnestunud kirjaviisireformi raamis.

\subsection{Astmevaheldus ja grammatika}

Ahrensi grammatika vormiõpetuse osas leidub julgeid, otse tänapäevastena tunduvaid teoretiseeringuid. Juba astmevahelduse paigutamisel vormiõpetusse oli ta oma ajast ees ligi poolteist sajandit! Selles polnud Ahrens oma ajas üksi - ka Faehlmann ja hiljem Wiedemann nägid astmevaheldust morfoloogia vahendina, Wiedemann Ahrensit järgides. Flektiivsete ja sufikseeritud käänete eristamine on mõte, milleni kaugeltki kõik tänapäevased keeleõpetajad ja grammatikakirjutajad pole küündinud. Ja siis veel essiivi toomine käänete hulka. Ta polnud üksnes kirikukeele reformija, vaid iseseisev keelemõtleja, kes suutis ühe suure tööga iganenu asemele rajada uue ja kestva süsteemi.

Astmevahelduse käsitlemine on läänemeresoome keelte grammatikates ülioluline nii praktiliselt kui ka teoreetiliselt - viimast seetõttu, et astmevahelduse koht keelekirjelduses ning meetod, kuidas astmevaheldust kirjeldatakse, defineerib ja diagnoosib suurel määral kogu grammatilise mõtlemise taset. Soome keele puhul oleks mingilgi määral põhjendatud astmevahelduse käsitamine vormimoodustuse foneetiliselt defineeritava saatenähuna, sest soome keeles on suurel määral (kuigi mitte absoluutselt) säilinud tugeva ja nõrga tüvevariandi sõltumine teise silbi lahtisusest või kinnisusest, mis omakorda sõltub sellest, 
kuidas vormimoodustussufiksid vormivad sõnatüve 2 . silbi kas lahtiseks või kinniseks: jalka: jala/n, palkka: palka/n. Eesti keele puhul pole teoreetilistki õigustust eriastmeliste tüvevariantide käsitamiseks muuna kui morfoloogiliste vormide eristamise flektiivse vahendina, sest eesti astmevahelduses ei sõltu tüveastmed 2. silbi lahtisusest või kinnisusest: jalga : jala, palka : palga on kõik lahtise 2. silbiga. Sellest hoolimata on lugematutes eesti keele kooliõpikutes ja eesti keele grammatikates astmevaheldust käsitletud foneetikasse kuuluva nähtusena.

Pikkadele vokaal- ja konsonantfoneemidele ehitatud morfoloogia on paratamatult vastuoluline. EKG I (1995: 102) postuleerib 9 lühikest ja 9 pikka vokaalfoneemi ning 17 lühikest ja 17 pikka konsonantfoneemi. Sellise nomenklatuuriga astmevaheldust ja morfoloogiat kirjeldades muutub suur osa algupärastest astmevaheldustüüpidest foneemiasendusteks, mis on lähedased supletiivsusele; assimilatsioonina käsitletud astmemuutustes $/ \mathrm{nt} />/ \overline{\mathrm{n}} /, / \mathrm{rt} />/ \overline{\mathrm{r}} /, / \mathrm{mp} />/ \overline{\mathrm{m}} /$, nagu $\left(/ \mathrm{s}{ }^{\prime}\right.$ unti $/$ : /s'uñi/, / k'ort/ : /k'ora/, /'empa-/ : /'ema-/ jt (ÕS-i tavaortograafias s'undi: sunni, $k$ 'ord: korra, 'embama : emmata) sulandub sonorandiga assimileerunud klusiil ühte pikka konsonantfoneemi, justkui oleks tegemist klusiili kaoga (vrd EKG I 1995: 157). Veel supletiivsem on laadiva-

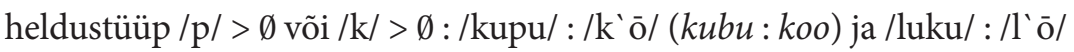
(lugu: loo); pikk vokaal lahutab need näitesõnad teistest samasse astmevaheldustüüpi kuuluvatest sõnadest, millel ka nõrgas astmes mõlemal vokaalil on vaste: óde : óe, tegu : teo, kägu : käo, pidu : peo, luba : loa jpt (vt ka EKG I 1995: 368).

Tugevneva astmevahelduse kirjeldus on eelmise peegelpilt selle lisaraskusega, et nõrga astme vormist tugeva astme tuletamine ei ole üheselt määratud: $/ \overline{\mathrm{n}} />/ \mathrm{nt} /, / \overline{\mathrm{r}} />/ \mathrm{rt} /, / \overline{\mathrm{m}} />/ \mathrm{mp} /: /$ 'añe/ $: /$ ante/, /p'ure/ : / p'urte/, /s'amāal/ : /s'ampla/ jt (EKG I 1995: 159; ÕS-i tänapäevases, nt ÕS 2013 ortograafias anne: 'ande, purre: p'urde, sammal : s'ambla).

Eesti astmevahelduses säilinud reeglipärad muutuvad pikkade foneemide kontseptsioonis palju ähmasemaks ja kaob ka side soome keele ja kogu läänemeresoome astmevahelduskäsitlustega ning keeleajalooga. 
Soome keele fonoloogias ei peeta pikkade vokaalide ja pikkade konsonantide kontseptsiooni mõistlikuks, kui käsitletakse kogu fonoloogilist süsteemi - pikad hälikud on sellises käsituses kaksikvokaalid ja kaksikkonsonandid (Karlsson 1972: 70-72). Eesti keele fonoloogias on pikkade foneemide postuleerijatel eespool nimetatud probleemidest onnnestunud mööda vaadata ainult seetõttu, et morfoloogiat on enamasti kirjeldatud Ahrensi ortograafias (mida aeg on mõistlikul määral modifitseerinud). Soome keele süstemaatilises grammatikas kuulub astmevaheldus morfofonoloogiasse (Karlsson 1972: 323). Soomlastele mõeldud eesti keele grammatikas on astmevaheldus morfoloogia sissejuhatavaks peatükiks 1982. aastal ilmunud Hannu Remese grammatikas “Viron kielioppi”. Just samal ajal katsetati Eesti koolides uue eesti keele õpiku käsikirja, milles esimest korda eesti kooligrammatikate ajaloos astmevaheldus on morfoloogiliste vormide moodustamise ja eristamise vahend, mitte häälikusüsteemi osa (Hint 1983).

Ahrensi grammatika järgib soome keele grammatika esitamise loogikat. Ahrens ise rõhutab nii põhimõttena kui ka näidetes ja loendites oma ortograafia soome eeskuju ning eesti sõnakujude tuletamise võimalikkust soome sõnadest (Ahrens 2003 [1853]: § 57, lk 120).

Siiski on üks teema, mille puhul Ahrens läheb oma teed: laadivaheldusprotsesside käsitlemisel on tal astme nõrgenemine (Ahrensil tenuatsioon) ja tugevnemine (firmatsioon) esitatud võrdväärsetena, justkui oleks nõrgast tüvevariandist tugeva tuletamine sama reeglistatav kui tugevast tüveastmest nõrga tuletamine. Selline käsitlus lähtub nn sõnaraamatuvormist (käändsõnade puhul nimetav kääne, verbide puhul $d a$ infinitiiv), aga tulemuseks on laadivahelduse (mutatsiooni) kirjeldamine juhul nagu näiteks roog : roa klusiili elimineerimisena (elisioonina) ning juhul nagu sae : saagida klusiili sisestamisena (insertsioonina; vt nt Ahrens 2003 [1853]: \$ 49, lk 115); tegelikult kuuluvad laadivaheldusjuhud $\operatorname{roog}(a)$ : roa ja $\operatorname{saag}(i)$ : sae ühtede ja samade reeglite alla (vt allpool).

Ahrensi elisiooni-insertsiooni meetodi läbiviimine ei ole võimatu, nagu Ahrensi grammatikast poolteistsada aastat hiljem näitab ka Eesti 
Keele Instituudi nn akadeemiline grammatika (EKG I 1995: 157-159 jm), aga laadivahelduse puhul tuleb astmevaheldusreeglit täiendada sõnaloenditega (EKG I 1995: 351-399), kusjuures isegi sõna arvamine astmevaheldusloendisse ei ütle nõrgast astmest lähtumise korral ühemõtteliselt, milline teisendus nõrga astme vormile osaks saab: kas ohe: 'ohke või ohe : 'ohte, või et õige on hälve : $h$ 'älbe, mitte ${ }^{\star} h$ 'älve, kuigi on valve: v'alve, mitte ${ }^{*} v$ 'albe (vt ka EKG I 1995: 159, 374-375). Samamoodi on toimitud "Eesti keele käsiraamatus" (Erelt jt 2007: 209-223). Tugevaastmelisest tüvevariandist lähtudes on vaja teada ainult seda, et sõna on laadivahelduslik: 'ohke ja 'ohte kaotavad ühtmoodi 2. silbi algulise klusiili. Isegi häälikuvälte teooriast (deklaratiivselt) lahtiütlemise puhul ei pea nõrga astme vormist selguma, kas tüvi on laadivahelduslik (hälve : $h$ `älbe) või kuulub hilise vältevahelduse valdkonda (valve : $v^{\prime}$ alve), sest hiline prosoodiline vältevaheldus hõlmas ka astmevahelduse varaste liikide - laadivahelduse ja geminaatklusiilide vahelduse poolt genereeritud sõnavormid, nii nagu iga lisanduv häälikumuutus hõlmab paratamatult kogu varasema sõnavara ja vormistiku.

\subsection{Hiline (prosoodiline) vältevaheldus}

Ahrensi ajal hakkas eesti keele alases debatis esile kerkima äratundmine, et mitmed olulised hääldusseigad on senistes grammatikates ja sõnaraamatutes jäänud märkamata-märkimata. Ka Ahrens kirjeldab kaht liiki $\ddot{o}$-d, aga Masingu loodud $\tilde{o}$-d ei pea ta vajalikuks kasutada, sest eestlane teab ilma uue tähemärgitagi, millal missugust $\ddot{o}$-d ütelda (Ahrens 2003 [1853]: $§ 39,1 \mathrm{k} \mathrm{108;} \mathrm{seevastu} \mathrm{näiteks} \mathrm{Wiedemann} \mathrm{pidas} \tilde{o}$-tähte enesestmõistetavaks).

Oli vaja Faehlmanni, et juhtida tähelepanu II ja III välte (aktsendi) erinevusele (Faehlmann 2002 [1852]: 235, 257-258 jm). Faehlmanni ortograafiaalased ettepanekud ei küüni Ahrensi ortograafia mõistmiseni, ta jääb vana kirjaviisi pooldajaks (vt ka Kask 1958: 47-50), aga prosoodilise vältevahelduse märkajana on tema mõtted tõlgitavad tänapäevasteks: "Elementarisch gleiche Silben werden verschieden accentuirt; 
AHRENSI ÕLGADEL

in Verwechselungsgefahr bezeichne man die betonte Silbe mit einem Accent ..." (Siret Rutiku tõlkes: "Elementaarselt sarnased silbid aktsentueeritakse erinevalt; äravahetamisohu korral tuleb rõhuline silp tähistada aktsendiga...”; vt Faehlmann, samas). Tänapäevases terminoloogias kõlaks see nii: segmentaalkoostiselt sarnaseid silpe võidakse aktsentueerida erinevalt ning segimineku ohu korral tähistatakse aktsentueeritud silp erimärgiga. See on just see, mida silbivälte teoorias tänapäeval tehakse (tehniliselt küll teistmoodi). Faehlmanni näidete hulgas on erivältelised genitiivi, partitiivi, illatiivi (Genitiv, Indefinitiv, Ingressiv) jt käänete vormid sõnadest nagu koti : kotti (vanas kirjaviisis kirjutati mõlemad vormid kotti), sõrme: 'sõrme, linna: 'linna, oinas: 'oinas, oinast : 'oinast jt (näited on siin tänapäevases märkimisviisis, Faehlmann kirjutas aktsendimärgi 2. silbi vokaali kohale, nt oinás). Sporaadiliste näidetena oli Faehlmann prosoodilist vältevaheldust käsitlenud juba oma astmevahelduse käsitluses "Ueber die Flexion des Wortstammes in der estnischen Sprache" (Faehlmann 2002 [1843]: 37-49; 50-60).

Ahrensi grammatikas hiline vältevaheldus ei kajastu ja on päris õnn, et vältevaheldust pole ka hiljem valatud üldkehtivasse ortograafiasse, hoolimata sellekohastest taotlustest kolme häälikuvälte teooria valitsemise ajal ning tolle teooria põhjal konstrueeritud eesti keele ortograafia nn kahest põhireeglist (nendest allpool). Ahrens ei oleks kuidagi võinud teada, et peagi pärast tema surma (1863) jõuab Mihkel Veske Leipzigis õppides kolme häälikuvälte teooriani ning esitab sellest lähtudes ka oma kirjaviisiettepanekud. Õnneks ei tulnud Veske kirjaviisiettepanekud kasutusele.

Et nii hästi läks, selles on ilmselt teened ka Jakob Hurda brošüüril "Lühikene õpetus õigest kirjutamisest parandatud viisi" (2012 [1864]: 213-228), milles Hurt selges eesti keeles propageerib, seletab ja täiendab Ahrensi ortograafiat. Hurdal on juba kõik eesti keele 9 vokaali (ka O. W. Masingu leiutatud $\tilde{\text { ) }}$ ning - mis kõige tähtsam -, ta toob ülima selgusega eesti keele häälikuõpetusse kerge ja terava rõhu (tänapäeval juurdunud terminoloogias II ja III välte) prosoodilise vastandumise sõnavormi pikkades rõhulistes esisilpides (tabel 5): 
TABEL 5. Kerge ja terava rõhu prosoodiline vastandumine sõnavormi pikkades rõhulistes esisilpides Jakob Hurda järgi

\begin{tabular}{|l|l|}
\hline Kerge rõhuga & Terava rõhuga \\
\hline metsa ladvad & metsa minema \\
\hline linna rahvas & linna minema \\
\hline laeva mastid & laeva astuma \\
\hline rahvast õpetama & rahvast juttu tegema \\
\hline puu juure peal & puu juure minema \\
\hline lauda lävi & kaks lauda \\
\hline
\end{tabular}

See käsitlus on tagantjärelevaates erakordselt tähelepanuväärne: terve sajand enne ühel või teisel viisil F. J. Wiedemanni eesti keele grammatikast (1875) lähtuvaid eesti keele silbiprosoodia tänapäevaseid seletusi (Valter Tauli, Robert T. Harms, Tiit-Rein Viitso, Mati Hint, Martin Ehala jt) seletas Hurt pikkade sõnaalguliste rõhusilpide välteerinevust prosoodilise, mitte segmentaalhäälikulise erinevusena. Hurt ei eralda nn "lihthäälikuid" (nagu linna ja 'linna, juure ja 'juure) ja "liithäälikuid" (diftonge ja konsonantühendeid) eraldi rühmadesse, vaid käsitab kõiki pikki rõhusilpe ühesuguselt prosoodiliselt aluselt. Teiseks on tähelepanuväärne seegi, et Hurt käsitab segmentaalselt (häälikuliselt) samastena, aga prosoodiliselt vastanduvatena erinevate lekseemide vorme: lauda lävi ja kaks lauda (mitte vastandades lauta : lauda, nagu hiljem muutus kooligrammatikates ekslikuks tavaks). Kolmandaks on tähelepanuväärne, et Hurt ei tõmba kerge ja terava rõhu vastandamisse lühikese esisilbiga sõnu; ta ei konstrueeri ahelat nagu nt lina - linna 'linna. Hurda arusaamad eesti keele prosoodiast on täiesti tänapäevased. Kui lisada, et Hurt mõjutas F. J. Wiedemanni arusaamu eesti keelest (paljude allikate hulgas vt nt Põldmäe 1988: 38-41 jm), siis ei ole ootamatu, et Hurda ja Wiedemanni käsitus eesti prosoodiasüsteemi eripärast on kongruentsed: Hurdal kerge ja terav rõhk, Wiedemannil kerge ja raske aktsent ehk kerge ja raske rõhk (Wiedemann 2011 [1875]: $\$ \$ 49-52$, lk 142-155). Wiedemanngi tunnistas, et selle nähtuse süstemaatiline 
kirjeldamine on raske (Wiedemann 2011 [1875]: 154 jm). Kuid on tähendusrikas, et Wiedemann sidus II ja III välte (tänapäises harjumusterminoloogias) erinevuse rõhuga ning võttis üle Faehlmanni termini aktsent (Accent), mille all ta eristas silbiga seostatult kerget (leichte) ja rasket (schwere) aktsenti või rõhku. Kui eluõiguse sai nn "rahvuslik keeleteadus" oma kolme häälikuvältega, siis jäeti hilise vältevahelduse käsitamine silbiprosoodia nähtusena kõrvale.

Hiline vältevaheldus on ka eesti keele kolmest astmevahelduse liigist - laadivaheldus, geminaatklusiilide astmevaheldus, hiline vältevaheldus - ainus, mille kirjeldamisel pikkade vokaalfoneemide kontseptsioonis ei kaasne suuri teoreetilis vastuolusid ja praktilisi kirjeldamisraskusi. Aga seda ainult juhul, kui loobutakse häälikute kolme välte ja häälikuühendite kahe välte valeteooriast ning mõistetakse, et hiline vältevaheldus on rõhulise silbiga seotud prosoodianähtus, millega ei kaasne segmentaalfoneemide erisusi: /k'óli/ ja /k'ōli/, /s'auna/ ja /s'auna/, /m' etsa/ ja /m'etsa/ on paariviisi ühesuguse segmentaalse ehitusega mõlema kontrasteeruva välte korral. Kahe silbi vahel jagunev pikk konsonantfoneem jääb probleemiks igal juhul: /k'on̄a/ ja /k'oña/ (vt eespool "Konsonantism"; vrd EKG I 1995: 150 jm).

\section{4. "Rahvuslik keeleteadus" kui eesti keeleteaduse umbtee}

\subsection{Eesti rahvusliku keeleteaduse sünd}

Ahrensi osa eesti kultuurkeele kujundamisel on otsustava tähtsusega sündmus eesti identiteedi kinnistumise ajaloos. Võitlus uue kirjaviisi poolt ja vastu käivitus peaaegu kohe pärast Ahrensi grammatika 2. trüki (1853) ilmumist. Kirjaviisireformi väitlustes oleks eesti keele ortograafiale suureks ohuks võinud saada Mihkel Veske nõutud foneetiline kirjaviis, mille järgi oleks tulnud II ja III välde kirjutada erinevalt ka hilise vältevahelduse korral: kirja ja kirrja, põhja ja põhhja jne (või mõnel muul moel neid välteid kirjapildis eristades; Veske 1879). 
Katse leida eesti keele kirjeldamiseks täiesti iseseisev raamistik viis eesti keele uurimise mitmes valdkonnas - eelkõige hälikusüsteemi ja prosoodia ning astmevahelduse uurimisel - rohkem kui sajaks aastaks ummikteele. Ahrensile hakati ette heitma, et ta ei leidnud üles kolme häälikuväldet ja ei rajanud oma ortograafiat sellele õpetusele. Karl August Hermann kirjutab oma entsüklopeediakatses Ahrensile pühendatud artiklis: "Nõnda ei ole Ahrens kolmest pikkusejärgust midagi teadnud...” (Hermann 2001 [1900-1903]: 210). 1884. aastal oli Hermann avaldanud oma eestikeelses eesti keele grammatikas õpetuse "Häälikute kolmest pikkuse järgust" (Hermann 1884: 5 jj), mis mõistagi oli üle võetud Ado Grenzsteinilt ja Mihkel Veskelt (Grenzstein 1876; Veske 1879; vrd Hint 2013). Kuid ka Hermann ei järgi Mihkel Veske ortograafiaettepanekuid, mis nõudsid II ja III välte järjekindlat eristamist täheortograafias. Tänapäevase tarkusega saab ütelda, et Veske tõlgendas silbi prosoodilisi häl̈lduserinevusi (II ja III välte erinevust) segmentaalselt, häälikute pikkuse erinevusena, ning nõudis prosoodilise erinevuse väljendamist täheortograafias. See on teoreetiliseltki küsitav.

Arnold Kask on korduvalt käsitlenud 19. sajandi teise poole kirjaviisiväitlusi (kõige põhjalikumalt monograafias "Võitlus vana ja uue kirjaviisi vahel XIX sajandi eesti kirjakeeles”, 1958), kuid kõigisse tolleaegsetesse hinnangutesse tuleb suhtuda vajaliku ettevaatusega: kellele tahes antud hinnangute taustaks oli Arnold Kase ajal kolme häälikuvälte teooria, sest 1950-ndatel ei kahelnud Eestis keegi, et eesti keeles on erinevalt kõigist teistest keeltest hälikutel kolm pikkusjärku ehk väldet. Ka Arnold Kask kirjutab enesestmõistetavalt üksikhäälikute väldetest (nt 1958: 49, 113, 158, 172); segmentaalse ja prosoodilise kvantiteedi erinevus ei kerki otseselt teemaks isegi Jakob Hurda brošüürile pühendatud peatükis. Ka võib tolleaegsetes käsitlustes näha kirikut halvustava riikliku ideoloogia mõju: kirjaviisivõitlusele pühendatud monograafias ei saa uue kirjaviisi looja Eduard Ahrens isegi omaette peatükki, küll aga saab omaette peatüki Vene Teaduste Akadeemia mõju eesti ortograafia kujunemisele. 
Tõeliselt rahvuslik eesti keeleteadus algab Fr. R. Faehlmannist, Eduard Ahrensist, Jakob Hurdast ja F. J. Wiedemannist, mis sest, et Ahrens kasutas eesti keelt ainult jumalasõnamisjonis. Need neli nime on teistest olulisemad just seetõttu, et nende panus on aja proovile vastu pidanud ja sobib vastuoludeta süsteemina kokku tänapäevaste arusaamadega. Hilisem, Veskest ja Hermannist algav eestikeelne keeleteadus on näinud väga palju vaeva, et kõigi tõeliselt rahvusliku eesti keeleteaduse nelja alusepanija töid ja arusaamu tõlgendada vildakalt ja vildakaks - kolme häälikuvälte teooria vaimus.

Faehlmann, Ahrens ja Wiedemann kirjutasid saksa keeles; sellest hoolimata kuuluvad nad eesti keeleteaduse suurkujude hulka, kelle vaated alles tänapäeval hakkavad saama neid väärivat mõistmist.

Faehlmann käsitles astmevaheldust kui morfoloogiliste vormide eristamise flektiivset vahendit; eelistas astmevahelduse käsitlemisel lähtevormina tugevaastmelist tüve; tõi eesti keele uurimisse II ja III välte (tänapäevases terminoloogias väljendatuna) eristamise.

Ahrens lõi eesti keelele sobiva ortograafia ja kirjutas grammatika (1843), mis lähtus eesti keelest enesest ning soome keele grammatikate eeskujust; käsitles astmevaheldust morfoloogia osana; andis oma grammatika 2., lauseõpetusega täiendatud trükis (1853) täis- ja osaobjekti kasutamise reeglid.

Hurt propageeris Ahrensi uut kirjaviisi, käsitles hilist vältevaheldust prosoodia nähtusena (1864); tema koostöö akadeemik Wiedemanniga mõjutas Wiedemanni sõnaraamatut (1869) ja Wiedemanni eesti keele grammatikat (1875).

Wiedemanni eesti-saksa sõnaraamat (1869) ja eesti keele grammatika (1875) kuuluvad tänapäevani eesti keele uurimise kõige tähtsamate allikate hulka; Wiedemann käsitles eesti keele välteerinevusi prosoodia nähtusena. 


\subsection{Võitlus uue kirjaviisi eest oli paradoksaalselt ka võitlus selle vastu}

Pärast Ahrensi surma (1863) hakkas ilmet võtma eesti soost eesti keele entusiastide keelealane tegevus, eeskätt eestikeelses ajakirjanduses ja ka 1872. aastal Tartus asutatud Eesti Kirjameeste Seltsis (juba varem Õpetatud Eesti Seltsis; seal küll saksakeelsena, eeskätt Fr. R. Faehlmanni keelealase tegevuse näol). Kui tähtsal kohal kujuneva eesti haritlaskihi jaoks olid kirjaviisiküsimused, seda on põhjalikult (kuigi 1950-ndatele paratamatu ideologiseeritud värvinguga) kajastanud Arnold Kask oma uurimuses "Võitlus vana ja uue kirjaviisi vahel..." (1958). Ahrensi uus kirjaviis hakkas võiduteed sammuma alles kümmekond aastat pärast Ahrensi surma (1863). Jannseni “Postimees" läks Ahrensi uuele kirjaviisile üle 1872. aastal.

Toda ajajärku on EKG I köite (1995) eessõnas iseloomustatud järgmiselt: "Möödunud sajandi teisel poolel tõusis päevakorrale eesti keele õpetamine eestlastele ja ühtaegu eesti keele kujundamine kultuurkeeleks. Seega aktualiseerus taas rakenduslik suund, mille eestvedajateks olid seekord juba eesti soost keelemehed. Ajajärgu alguseks võiks pidada Karl August Hermanni esimese eestikeelse grammatika "Eesti keele grammatik" (1884) ilmumist, kõrgajaks aga käesoleva sajandi [st 20. sajandi] kahekümnendaid-kolmekümnendaid aastaid..." (EKG I 1995: 5).

Tolle eesti keeleteaduse ajajärgu alguseks võib siiski pidada kirjaviisivaidlusi, mis algasid enne Karl August Hermanni grammatikat. Nondes vaidlustes paistsid silma peaaegu kõik ärkamisaja juhtivad eesti haritlased: Fr. R. Kreutzwald, Carl Robert Jakobson, Jakob Hurt, Mihkel Veske, Ado Grenzstein... Viimased kaks, eriti aga Mihkel Veske oma õhukese raamatuga "Eesti keele healte õpetus ja kirjutuse viis" (1879), algatasid eesti keele häälikusüsteemi uue tõlgenduse, mis valitses ainulisena 1960-ndate aastateni, üldhariduskoolis ja suuresti ka ülikooliõpetuses 1980-ndateni, eesti keele aabitsates ja populaarsetes ülevaadetes aga elab tänapäevani ja tulevikuski. Selles õpetuses on eesti keeles erinevalt teistest keeltest hälikutel kolm pikkusastet (I, II, III välde; välte-sõna 
AHRENSI ÕLGADEL

pärineb nähtavasti Grenzsteinilt) ning häälikuühenditel kaks väldet (II ja III). Häälikulooliselt väga olulise prosoodilise uuendusena mõlemasse eesti keelde (nii põhja- kui ka lõunaeesti keelde) arenenud hilist vältevaheldust hakati tõlgendama segmentaalselt, häälikute, mitte silpide omadusena. Prosoodilist mõtlemisviisi praegu II ja III välteks nimetatava hällduse eristamisel esindas nimetatutest ainult Jakob Hurt, kes on mõjutanud ka Wiedemanni nüüd klassikaks kujunenud prosoodilist vältekäsitlust (Wiedemann 2011 [1875]: 142-155).

Praeguses vaates on selline eesti keeleteaduse ajalugu hämmastav. Kõik eesti keeleteadlased on pidanud saama hea keelejaloolise hariduse. Päriskeeleteaduseks peetigi noil aegadel ainult keeleajalugu. Nii kaua kui keeleajalugu on Eesti filoloogilises kõrghariduses õpetatud, peaks olema saanud kõigile eesti filoloogidele selgeks, et hiline vältevaheldus tekkis silbiga seotud tingimustel: põhirolli mängisid sõnavormi esisilbi pikkus ja teise silbi lahtisus või kinnisus ning keeleajalooline silpide arv

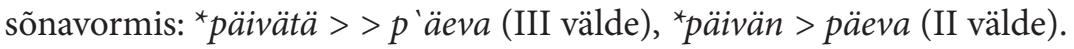
Niisuguse prosoodilise vastanduse tekkimine oli eesti keele jaoks väga otstarbekas, sest see võimaldas paljudes sõnatüüpides säilitada osa- ja täissihitise traditsioonilise eristamise: Ta ootas seda päeva ja Ta ootas selle päeva ära.

\section{3. "Eesti rahvuslik keeleteadus"}

Toomas Help on artiklis "Eesti ja soome keele suhted: Wiedemann Ahrensi ja Veske vastu” Mihkel Vesket ja Karl August Hermanni esitanud kui eesti rahvusliku keeleteaduse loojaid, kelle keeleajalooline käsitlus vastandub Wiedemanni sünkroonsele keelekirjeldusele: "XIX sajandi viimase kolmandiku algupoole rahvusliku liikumise taustal tekkis e esti rahvuslik grammatikatraditsioon, mis vastandus varasemale grammatikakirjandusele eelkõige oma teooriavälisest küljest: nüüd kirjeldati eesti keelt esmakordselt eestlaste poolt eestlaste jaoks eesti keeles. Kaks esimest tähtsat teost seda laadi käsitluste seas olid M. Veske hälikuõpetus ning K. A. Hermanni grammatika." (Help 1988: 202) Help 
väidab, et sünkronistist Wiedemann seisis põhimõtteliselt vastu uue rahvusliku põlvkonna ajalookesksele keelekontseptsioonile (samas, lk 203). Uue põlvkonna (Veske ja Hermann) keeleajalookesksus on eksitus.

Veske ja Hermann on küll esimesed eesti soost kõrgete akadeemiliste kraadidega keeleteadlased ja ka eestikeelse eesti keeleteaduse algatajad - Veske oma süstemaatilise häälikuõpetusega ja Hermann hääliku- ja vormiõpetust hõlmava eestikeelse grammatikaga -, aga nende mõtteviis eesti foneetika ja ortograafia esitamisel ei põhine keeleajalool, mida nad kahtlemata olid tundma õppinud, sest Veske ja Hermann olid oma keeleteadusliku hariduse saanud Saksamaal.

Mihkel Veske "Eesti keele healte õpetus ja kirjutuse viis" (1879) esitab raamatu lõpuosas ( $\$ \$ 79-107,1 \mathrm{k} 82-104$ ) nõrga ja tugeva astme keeleajaloolise kujunemise käigu peatükina "Sõnatüve pehme ja kõva muutuste saamise seadused", aga see häälikuajalugu ei mõjuta kuidagi raamatu põhiosas esitatud eesti häälikusüsteemi kirjeldust, mille sisuks on eesti keele häälikute kolm pikkuse järku, ühendatud häälikute (hilisemas terminoloogias "liithäälikute" - diftongide ja konsonantühendite) kaks pikkuse järku, sisehäälikud ( $\$ 63,1 \mathrm{k} 57 \mathrm{jm}$ : sisemised healed) ning sõna eri vormides sisehälikute muutuste võrdlemise teel tugeva ja nõrga astme eristamine pluss selle õpetuse järgi kujundatud ortograafiareformi ettepanekud. See analüüs on täiesti sünkroonne ning läbi viidud metoodikaga, milles on hilisemate fonoloogiateooriate elemente. Mihkel Veske foneetikateooria võeti tärkavas eesti keeleteaduses ja hiljem eestikeelse kooli eesti keele õpikutes täiel määral üle (ortograafiaettepanekuid siiski mitte) ning sellest kujunes eesti keele foneetika, fonoloogia ja morfofonoloogia peavool rohkem kui sajaks aastaks. See sada aastat on eesti keele hälikusüsteemi ja astmevahelduse olemuse seletamise pikk eksitee, mis ei lõpe niipeagi, sest see on tavateadvusse viidud rahvusliku identiteedi koostisosana, mida eesti keele aabitsates ja populaarsetes käsitlustes aina ja aina korratakse.

K. A. Hermanni "Eesti keele Grammatik" ei esinda mingiski mõttes keeleajaloolist vaatepunkti, vaid järgib Mihkel Veske "Eesti keele healte õpetuse ja kirjutuse viisi" sünkroonset osa ja Hermanni enda 
doktoriväitekirja (Leipzigis 1880). Vähesed keele varasematele seisunditele vihjavad märkused on Hermannil pealiskaudsed või koguni kaheldavad (nt "Võib olla, et väga kaugel ennemuistsel ajal Eesti keele sõnade juured kõik ühesilbilised olivad...”; \$31, lk 18).

"Rahvuslik" foneetikateooria on ekslik. Eksituse põhimomentid on järgmised: 1) rõhusilbi (üldiselt esisilbi) prosoodilisi erinevusi (II ja III välte erinevat häldamist) tõlgendatakse häälikute ja häälikuühendite ("liithäälikute") II ja III vältena; 2) prosoodilisse vastandusse tõmmatakse kaasa segmentaalselt lühikese esisilbiga (I välte) sõnad - nii saadaksegi muudest keeltest erinevalt eesti keele häälikutele kolm pikkusjärku (kalu : selle kaalu, seda 'kaalu); konsonantide puhul tähendab see, et vastandusse kaasatakse I vältena 2. silbi alguline hälik, millel saab foneetiliselt olla ainult omakestus (kabi : kapi : kappi); 3) eesti häälikusüsteem liigitatakse lihthälikuteks ja liithäälikuteks; viimased koosnevad teistest häälikutest (diftongid ja konsonantühendid); hilisemates fonologiseeringutes muutuvad need liithäälikud foneemideks (nt Ariste 1953; Lehiste 2000 [1977]) - niisiis koosnevad eesti keeles ühed foneemid teistest foneemidest; see on mistahes fonoloogiateoorias päris võimatu vasturääkivus; 4) astmevaheldust käsitatakse foneetika nähtusena, nii nagu seda näeb keeleajalugu; see on ainus punkt, milles keeleajalooline vaateviis on nn eesti rahvuslikku keeleteadust mõjutanud - kuni 1980-ndate aastateni peeti kooliõpikutes astmevaheldust häälikuõpetuse osaks, kuigi sünkroonses keelekirjelduses ei ole vähimatki kahtlust, et üldkeeleteaduse seisukohalt on eesti keele astmevaheldus tüüpiline flektiivse morfofonoloogia nähtus, millel on oluline osa morfoloogiliste vormide eristamisel (nt jalg : jala : jalga).

Uus "rahvuslik" õpetus eesti häälikusüsteemist tõi kaasa lahkumise üldkeeleteaduse pinnalt, mida olid esindanud Faehlmann, Ahrens, Hurt ja Wiedemann. Peaaegu terve sajandi kestel leiti, et eesti keelt tuleb analüüsida teisiti, kui teisi keeli. Eesti keele kolm häälikuväldet, liht- ja liithäälikud (viimased oma kahe vältega) pidid justkui ümber lükkama või vähemalt täiendama üldkeeleteaduse tõdesid. Foneemiteooria ajastul esitati korduvalt seisukoht, et eesti keeles on eraldi foneemideks nii 
häälikute kolm kestusastet kui ka häälikuühendite välted, foneemide loend võib olla avatud ja umbes kümme või rohkem kordi ulatuslikum kui teiste keelte keskmine. Sellise teooria ümberlükkamine on olnud raske ka seetõttu, et eesti keeleteaduse kõige kõlavamad rahvusvahelised korüfeenimed Paul Ariste ja Ilse Lehiste jäid lõpuni truuks kolme välte teooriale koos kõigi selle teooria vastuoludega. Nüüdseks on teaduslikus kirjanduses selle vaatega näiliselt lõpp tehtud, aga ainult näiliselt ja deklaratiivselt.

Erinevalt Veskest ja Hermannist käsitlesid Ahrens ja Wiedemann eesti keelt üldkeeleteaduse (Ahrens ka soome keele, Wiedemann mitte) raamis. Wiedemann käsitles eesti silbiprosoodiat viisil (Wiedemann 1875), mille juurde sada aastat hiljem tagasi pöörduti ning mis on tänapäevastes eesti foneetika kirjeldustes mõningaste variantsustega üldtunnustatud. Aga sinna jõuti saja-aastase vaheajaga (umbes 1880-1980), mille kestel Ahrensit ja Wiedemanni käsitati keelemeestena, kes ei saanud aru eesti keele eripäradest.

Seejuures ei puudunud mõneski põhjalikumas eesti keele grammatikas astmevahelduse keeleajaloolise kujunemise lühiülevaade (nt Loorits 1923: 11; Muuk 1927: 23-24; Jänes 1966: 80-81), mis peaks suunama silbikeskse mõtlemise juurde. Sellisel taustal on tagantjärelevaates üllatav, kuidas prosoodiliste, silbiga seostatud häälikumuutuste tagajärjel tekkinud uuendus eesti prosoodiasüsteemis tõlgendati ümber häälikutega seotud nähtuseks. Samal ajal lülitati astmevaheldus keeleajaloo põhjal foneetika osaks, koguni sel määral, et Eestis ja eesti keeleteadlaste osavõtul koostatud soome keele õpikutes-grammatikates arvati astmevaheldus foneetikasse (nt Grammatika 1958; Palmeos 1963).

Näiteid "rahvuslikus keeleteaduses" valitsevast teoreetilisest segadusest häälikuväldete, silbiväldete ja astmevahelduse käsitlemisel leiaks igast õpikust või ülevaateteosest. Elmar Muuk oli sõjaeelse Vabariigi kõige silmapaistvam õigekeelsuslane ja õpikute autor, kelle poolt väljatöötatud kaanon häälikusüsteemi ja astmevahelduse käsitlemiseks leidis matkimist ka Eesti NSV-s. Selles kaanonis (nt Elmar Muugi "Eesti keeleõpetus I. Hääliku- ja vormiõpetus"; 1927) on keeleajaloolised tõed 
ja sünkroonne keelekäsitlus ning foneetika ja morfoloogia segamini: kõneldakse sõna astmetest, silbiväldetest ja häälikute astmevaheldusest; viimane esitatakse otse tabeli kujul, milles häälikutel on tugev ja nõrk aste, nii et näiteks tugevaastmelise konsonandi $b$ nõrk aste võib olla $\emptyset$ või $v$ - hälik vaheldub kaoga või mõne muu häälikuga, nagu tuba: toa ja leiba : leiva (Muuk 1927: 25; mõnes väljaandes nimetatakse seda ka häälikute laadivahelduseks, nt Muuk 1936: 27). Sellise sõnastuse korral ei ole astmevaheldus sõnatüve omadus, vaid häälikute võime esineda mitmel kujul, mis sellisena kuulub häälikuõpetusse, mitte morfoloogiasse. Kui selline õpetus oleks loogilise lõpuni arendatud, siis oleks tulnud väita, et häälik $b$ esineb ka hääliku puudumisena ja $v$-na, $v$ aga on mitmesugust algupära - on algne $v$ ja $b$ nõrgasastmeline vaste $v$. Keeleajalooliselt see ongi nii, aga tänapäeval ei ole mingit vahet, kas $v$ on algupärane (laeva) või tüve laadivaheldusprotsessi tagajärg (leiba : leiva). Kogu laadivahelduse repertuaar esitati häälikute vaheldumisena, mitte sõna tüvekujude vaheldusena. Teoreetiliseks-metodoloogiliseks toeks niisugusele tõlgendusele oli sisehäälikute mõiste.

\subsection{Sisehäälikuid ja häälikuvälteid ei ole võimalik ühendada silbivälte teooriaga}

Sisuliselt sama astmevahelduse seletuse esitavad Elmar Muugi eesti keele õpikud 1930-ndate aastete lõpuni (nt Muuk 1936: 27; Muuk \& Mihkla 1936: 80 jj; Muuk \& Mihkla 1938: 26 jj) ning see esitusmudel kandus üle ka sõjajärgsetesse eesti keele õpikutesse, kuni Eduard Vääri eesti keele keskkooliõpiku 10. trükini välja (Vääri 1980: 21).

Foneetikasse kuuluvate nähtuste (häälikute kvaliteedid ja silbipikkused) segiajamine grammatikasse kuuluvate nähtustega (astmevaheldus) muutus kõigutamatuks õpetuseks. Oleks õiglane märkida, et kõigist sõjaeelsetest grammatikutest ja õigekeelsuslastest oli Elmar Muuk nähtavasti ainus, kes kahtles kolme häälikuvälte teooria õigsuses (Muuk 1925) ja märkis oma "Väikeses õigekeelsus-sõnaraamatus" (1933) silbivälteid, mitte häälikuvälteid ('kont'sert, mitte kon 'tser't). 
Tänapäevased eesti keele esindusteosed deklareerivad küll hälikuvältest ja sellega seotud mõistestikust loobumist, aga tegelikkuses ollakse häälikuvältest loobumisest väga kaugel.

Suhteliselt hiljutine Mati Erelti, Tiiu Erelti ja Kristiina Rossi "Eesti keele käsiraamatu" kolmas trükk (EKK 2007: 209) defineerib astmevaheldust järgmiselt: "Sõna eri vormides esinevad tüvekujud võivad üksteisest erineda oma astme poolest, st välte või sisehäälikute poolest või nii välte kui ka sisehäälikute poolest, nt 'haara/ma: haara/ta, tõbi : tõve, 'ohka/ma : oha/ta. Astme poolest erinevate tüviallomorfide vaheldumist sõna morfoloogilises paradigmas nimetatakse astmevahelduseks".

Akadeemiliseks nimetatav EKG I (1995) defineerib astmevaheldust praktiliselt samasuguses sõnastuses: "Eesti keeles võib ühel ja sellelsamal tüvel olla eriastmelisi allomorfe, s.t allomorfe, mis erinevad üksteisest oma välte poolest ja/või sisehäälikute foneemkoostise poolest [---] Astme poolest erinevate tüviallomorfide vaheldumist sõna morfoloogilises paradigmas nimetatakse tüve astmevahelduseks" ( $\$ 115,1 \mathrm{k} \mathrm{144)}$. Joone all antakse ka sisehäälikute traditsiooniline (Mihkel Veskelt alguse saanud) definitsioon: "Sisehälilikuteks nimetatakse sõna tüvehäälikuid alates pearõhulise (või kaasrõhulise) silbi vokaalidest (incl.) kuni järgmise silbi vokaalideni (excl.), nt elama, kaste."

Sisehäälikute mõiste on vastuoluline konstrukt, kahtlane, kas seda mõistet üldse vaja on. Mihkel Veskel olid sisemised healed töövahendiks kõigi astmevaheldusliikide määramisel; ka hilise vältevahelduse puhul oleks Mihkel Veske ortograafias sisehäälikuid tugevas ja nõrgas astmes kirjutatud erinevalt: nt karja ja karrja. Kuna Ahrensi ortograafia silbiprosoodia ülekannet segmentaalsesse väljendusse ei võimalda, siis on sisehälikud hilise vältevahelduse astmete määramisel kasutud: sisehäälikud on II vältes karja ja III vältes ‘ karja puhul samased ning tugeva ja nõrga astme eristamine on võimalik üksnes mõlemas astmes kahesilbilisi kõnetakte võrdlevalt hääldades.

Võib paista, et EKG I (1995) saab aru sisehäälikute otstarbetusest hilise vältevahelduse kirjeldamisel. Aktsendi ja välte seose käsitlemisel kõneldakse rõhusilbi hääldamiserinevustest, mitte sisehäälikute 
erinevusest ( $\$ 88,1 k$ 113-114). Kuid eesmärgiks on ikka jõuda välja kolme erineva vältega kõnetaktide vastandumiseni (mis ei ole vale); seejuures väidetakse, et "kolmas välde vastandub teisele või (harvem ka) esimesele [---]”. Seegi väide poleks vale, kui näitesõnaks oleks pesa : p'essa või osa : 'ossa ning kui selliseid näiteid järjekindlalt käsitataks hälikusüsteemi võimaluste kasutamisena morfoloogias ja morfofonoloogias; kuid kui III ja I välte vastandamise näitesõnaks on $k^{\prime}$ oht : koha, siis on häälikusüsteemi võimaluste analüüs ja morfofonoloogia (laadivaheldus) segamini aetud ( $\$ 88,1 \mathrm{k} 114)$. Analüüsitasandite segiajamine eesti keele hälikusüsteemi ja morfofonoloogia-morfoloogia uurimisekirjeldamise tänapäevases peavoolus on probleem palju laiemaltki.

"Eesti keele käsiraamat" (EKK 2007: 63) annab peatükis "Kuidas määrata sõnaväldet" juhise: "Vältevastandus saab esineda ainult rõhulistes silpides. Seepärast on sõnavälte määramisel oluline jälgida sõna sisehälilikuid, st häälikuid, mis algavad (pea)rõhulise silbi esimese vokaaliga ja lõpevad järgmise silbi vokaali ees, nt ka-la, kal-lis, kau-nis, kar-tul, arheoloo-gia, põu-e. Morfoloogilistesse tunnustesse kuuluvaid häälikuid sisehäälikute hulka ei arvata, nt sõnas heintele ei kuulu $t$ sisehäälikute hulka: hein-tele".

Selline käsitus ja ka sõnastus on püsinud "Eesti keele käsiraamatu" kolmes trükis $(1997,2000,2007)$ muutmatuna. Arusaamatust ja segadust on käsiraamatu vältekäsitluses küllaga.

1. Käsiraamat eeldab, et välte määramisele (st sõnavormi häälikulisele analüüsile) peab eelnema morfoloogiline analüüs (näide heintele). Kuid sõnu suudetakse hälldada ka siis, kui nad on potentsiaalsed sõnad, millel tähendust pole või mille tähendust ja morfoloogilist koostist ei teata. Näide heintele on foneetilise-fonoloogilise ja morfoloogilise tasandi segiajamine. Aga kuidas määrata sisehäälikuid ja väldet vormides nagu $k \ddot{a}$-te, ve-tel? Või vormides nagu so/i/d, ma/i/d? Kas need sõnavormid on I vältes, kuna sisehäälikuks jääb käsiraamatu definitsiooni järgi ainult lühike vokaal? See on võimatu. Grammatiline homonüümia on eesti keeles väga ulatuslik; täpselt ühtmoodi hääldatavad homonüümid võivad saada erineva morfoloogilise analüüsi, kuna 
neil on erinev morfeemkoostis, kuid see ei saa mõjutada foneetilist analüüsi: nt sai 'nimisõna nom' ja sa/i 'saama-verbi imperfekt' on foneetiliselt eristamatud.

2. Sisehäälikute väljaeraldamine võimaldab määrata ainult I väldet ning lühikese ja pika esisilbi erinevust, aga II ja III välte erinevust mitte (kau-nis ja 'kau-nis on ühesuguste sisehäälikutega), kuigi just II ja III välte erinevus on eesti keele prosoodia põhiprobleem ning nn I välde on vastanduste ahelasse toodud kolme häälikuvälte teooria mõjul ja selle õigustamiseks (Hurdal see puudus). Ka EKK (2007: 63) tunnistab, et vältevahelduse korral saab II ja III välte erinevust määrata ainult häl̈lduse alusel - kahesilbilist (kõnetakti ulatusega) sõna või sõnaosa hääldades. Milleks siis sisehäälikud?

3. Märgatava kõhklusega tunnistatakse II ja III välte vastandus prosoodiasse kuuluvaks nähtuseks. "[---] peab enamik uurijaid vältevastandust vähemalt ositi suprasegmentaalseks nähtuseks" (EKK 2007: 61). Kogu seda peatükki ("Häälikute ja foneemide pikkus. Sõnavälde”) läbib kolme pikkusastme ideoloogia: hälilikud ja silbid on kas lühikesed, pikad või ülipikad: "Nii üksikut häälikut kui ka teatud silpe on eesti keeles võimalik hääldada kolme erineva pikkusega, mis annab sõnadele erineva tähenduse" (EKK 2007: 60). Ei ole nii: üksikut häälikut ei ole väljaspool kõnetakti kuidagi võimalik häldada kolme erineva pikkusega ning konsonantide puhul on esmavälteliseks tõlgendatud 2. silbi algulise konsonandi vastandamine silbipiirilistele geminaatkonsonantidele põhimõtteliselt väär, sest silbialgulisel konsonandil $(k a-\underline{l} a)$ on ainult omapikkus, mis konstrueeritakse vastanduma pika silbi lõpuna funktsioneeriva geminaadi esiliikmega, et saada kolm häälikuväldet kala kalla - ka'lla. Kolme sõnavälte kontseptsioon on sündinud kolmest häälikuvältest ning ajaliselt alles Grenzsteini ja Veske "teooria" järel; veel Hurdal oli selge arusaamine, et prosoodiline on üksnes pika rõhusilbi häldamine kas kerge või terava rõhuga; nn I välde ei ole üldse hilise vältevahelduse vältevastanduste objekt.

4. Kolme häälikuvälte teooria on käsiraamatus esindatud peatükis "Häälikute pikkuse märkimine". Nn eesti ortograafia põhireegel 
esitatakse sellisel kujul: "Kõik häälikud, v.a $b, d, g, f$ ja $\check{s}$, kirjutatakse ühe tähega, kui nad on lühikesed, ja kahe tähega, kui nad on pikad või ülipikad" (EKK 2007: 68-69; sama sõnastus on ka käsiraamatu varasemates trükkides). Reegli järel esitatakse täiesti traditsioonilises vaimus kolmikvastanduste näiteid nii vokaalide kui ka konsonantide osas (roogib kalu - elu on kaalul - kolm kaalu; ilus lina - suured linnad - nägi suurt linna jne). Ja edasi: "Lühikesed sulghäälikud kirjutatakse $b, d, g$, pikad $p, t, k$, ülipikad $p p, t t, k k$ [---]" Kolme häälikuvälte klassikalisteks näideteks on kabi - kapi - kappi, koda - kotad - kotta, lagi - laki - lakki (EKK 2007: 69). See on häälikuvälte teooria kõige ehedamal, Mihkel Veskest ja Ado Grenzsteinist päritud kujul.

Eesti ortograafia nn esimene põhireegel ("Kõik häälikud, v.a $b, d, g$ [---]") on käsiraamatus esitatud väga ebaõnnestunud sõnastuses; sellest pole võimalik aru saada isegi häälikuväldet uskudes: kas siis $b, d, g$ ei kirjutatagi lühikestena ühe tähega?

Ka eesti ortograafia nn teine põhireegel lähtub häälikupikkustest: "Häälikuühendis (kaashäälikuühendis või diftongis) kirjutatakse iga häälik ühe tähega, tema pikkusest olenemata: kupli, lahke, katsed, [---] linlane, kausjas, poeg, laul [---]." (EKK 2007: 69). Selline sõnastus ei jäta kahtlust, et häälikulise ja ortograafilise analüüsi sisuks peab käsiraamatu arusaama järgi olema häälikute pikkuse analüüs.

5. Häälikuvälte teoorias on alati olnud probleemiks (õieti võimatuseks) geminaatklusiilide astmevahelduse erinevate silbitüüpide, nagu looka : looga, lauta: lauda, panka : panga käsitamine-käsitlemine ühtse tüübina nii morfoloogias kui ka morfofonoloogias, sest häälikuvälte teoorias tuleb looka : looga ja lauta : lauda puhul määrata pika vokaali või diftongi välde ning sellele järgneva klusiili välde (EKK 2007: 68-70); panka : panga, märki : märgi jne puhul aga tuleks selle teooria järgi määrata vokaali (lühike) ja sellele järgneva konsonantühendi välde. Mis Faehlmannile, Ahrensile, Hurdale ja Wiedemannile oli enesestmõistetav, on "rahvuslikus keeleteaduses" ka selle keeleteaduse lipulaevadele mõistetamatu. Astmevahelduse ja morfoloogia kirjeldamisel (EKK 2007: $214 \mathrm{jj}$ ) on neid silbitüüpe (pank : panga, kaup : kauba, vaatama : 
vaadata) siiski käsitletud koos, nii et häälikuõpetus ja morfoloogia pole käsiraamatu kaante vahel unisoonis - häälikuõpetus on eriti truult kinni kolmes häälikuvältes.

Ahrensile oli täiesti selge nii ortograafia, astmevahelduse kui ka morfoloogia tasandil, et noot, laut, hurt on ühesuguste esisilbipikkustega, nad kirjutatakse ühe ja sama reegli järgi ning nende vaheldused (geminaatklusiilide astmevaheldus, Ahrensil emollitsioon) ja morfoloogia on ühesugused (Ahrens 2003 [1853]: \$ 65, lk 128-129).

6. Geminaatklusiilide astmevaheldust nimetab nii käsiraamat kui ka akadeemiline EKG I (1995) pikkusmuutuseks. Käsiraamat defineerib erinevate astmevaheldusliikide suhet järgmiselt: "Pikkusmuutus on vältemuutuse alaliik" (EKK 2007: 214). Ei ole! Nn pikkusmuutus on astmevahelduse üks algseid liike (koos laadivaheldusega) ning hiline vältevaheldus lihtsalt hõlmas kõik keeles olemas olevad sõnavormid, kui häälikumuutuse (III ja II välte eristumise) tingimused selleks sobisid. Nii on häälikumuutuste puhul põhimõtteliselt alati. Nn pikkusmuutuse alla kuuluvad tõepoolest geminaadist ühe klusiili väljalangemisega muutusetüübid 'panka: panga, 'kaupa: kauba, 'vaata/ma: vaada/ta, kuid täiesti kindlasti mitte pikkusmuutusega kokku pandud vaheldusjuhud rõngas : 'rõnga või seade : 'seade; viimased on tüüpilised hilise (prosoodilise) vältevahelduse juhud, seade : 'seade pealegi hiline tuletis, mis hästi ei sobitugi eesti hälikusüsteemi ( $e a$-diftong on tüüpiliselt III-vältelise, aga mitte II-vältelise silbi diftong). Geminaatide astmevaheldus on segmentaalne, nagu laadivahelduski, aga hiline vältevaheldus ei ole segmentaalne.

Kogu selle ebavajaliku segaduse põhjuseks on suutmatus lahti ütelda kolme häälikuvälte valeteooriast ning lahkulöömine üldkeeleteaduslikust vaatepunktist; selle tulemusena loobutakse soome keele ja eesti keele morfofonoloogia olulise ühisosa tunnustamisest ning eesti keele tõeliste erijoonte selgest väljaeraldamisest.

7. Katse lahti ütelda häälikuvälte teooriast siiski tehakse nii käsiraamatus kui ka akadeemilises grammatikas EKG I (1995). Käsiraamatus (EKK 2007: 62) esitatakse eesti prosoodia skeem, mis peaks olema 
põhimõtteliselt vastuvõetav enamikule eesti prosoodia uurijatest, kes ei lähtu hälikuvältest (Wiedemannist Martin Ehalani): lühike rõhuline silp on I välde, pikka rõhulist silpi aga saab hääldada kerge või raske aktsendiga, mis liigitatakse vastavalt II ja III välteks:
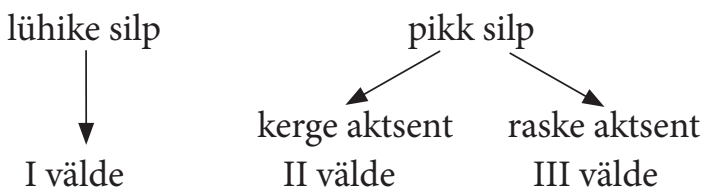

"Niisiis on eesti keele kolme välte vastandus fonoloogiliselt kirjeldatav kahe kaksikvastanduse summana: 1) segmentaaltasandil vastanduvad lühikesed ja pikad foneemid (ja silbid); 2) suprasegmentaaltasandil jagunevad pika rõhusilbiga kõnetaktid kerge- ja raskeaktsendilisteks" (EKK 2007: 62). Teise vastanduse sõnastusega saab ainult nõustuda, kasutatagu siis missugust terminoloogiat tahes.

Kahjuks on see iseenesest õige skeem käsiraamatus (osalt ka akadeemilises grammatikas) butafoorne. Mõistlikule skeemile eelneb ja järgneb käsiraamatus pidev jutt lühikestest, pikkadest ja ülipikkadest häälikutest. Mõistetakse küll, et häälikuvälte aeg on möödas, aga silbivälte või kõnetaktivälte olemust kirjeldada ilma kolme häälikuvälteta ei suudeta. See on nagu kerakujulise Maa ja lapiku Maa arusaamade võitlus kerakujulise Maa teadmise algfaasis. Teati juba, et Maa on kerakujuline ja et on võimalik ümber Maa purjetada, aga maakaardid joonistati ikka selliselt, et taldrikukujulist Maad katab taevakumm, mis äärte peal tuleb maapinnale nii lähedale, et Jäämere taga saavad elada ainult pudelipikkused pügmeed. Selliseid maakaarte trükiti koguni meresõidukeskustes Antwerpenis (nt 1579. aastal) ja Veneetsias (nt 1596. aastal), kuigi ümbermaailmapurjetamised olid juba tõsiasi.

Käsiraamat lähtub (nagu ka EKG I 1995) lühikeste ja pikkade foneemide vastandamisest eesti keeles. Ka astmevaheldust lubatakse kirjeldada, lähtudes lühikestest ja pikkadest segmentaalfoneemidest (EKK 2007: 61). Õnneks seda siiski ei tehta (teisiti EKG I 1995, mis järgib seda 
lubadust), vaid astmevaheldust (EKK 2007: 208-223) ja morfoloogiat kirjeldatakse Ahrensi ortograafias, mistõttu see on - kõigist küsitavustest hoolimata - hõlpsasti jälgitav. Fonoloogiamängud ja originaalitsemise taotlused eesti keele kulul ongi osalt olnud võimalikud seetõttu, et morfoloogia kirjeldamisel oma postulaate ei rakendata, vaid morfoloogiat kirjeldatakse Ahrensi ortograafias.

"Eesti keele käsiraamatu" 1. trükiga samal aastal ilmunud Martin Ehala "Eesti keele struktuur. Õpik güm[n]aasiumile" (1997) esitab "Eesti keele käsiraamatust" oluliselt erineva fonoloogilise tõlgenduse: pikki foneeme pole, pikad häälikud on kahe ühesuguse foneemi järjendid (Ehala 1997: 63 jm), silbipikkuste skeemi ja ka seletuse järgi "III välde on iseäralik rõhk, millega võib häldlada pikki silpe” (Ehala 1997: 62).

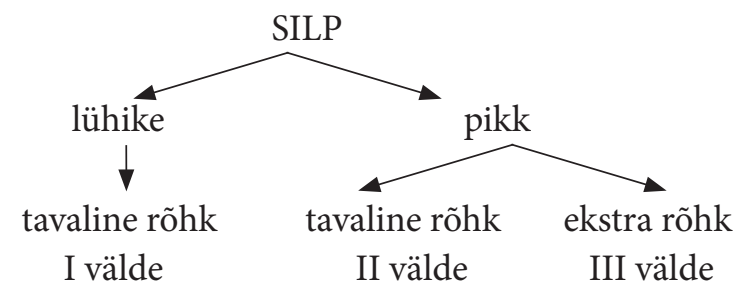

Silbivälte skeemid siin viidatud käsitlustes on terminoloogia erinevustest hoolimata sisuliselt samased, aga pikkade foneemide küsimus on otsustatud vastandlikult; käsitluste olulisim erinevus on selles, et käsiraamat pole suutnud loobuda kolmest häälikuvältest, Ehalal on see korda läinud, kuid sõnakasutuses ähvardab kolme häälikupikkuse tont ka teda: "[---] eesti keele häälikutel ei ole kolme pikkusastet, sest üks arvatav pikkusaste - ülipikk häälik tuleneb ju erilisest rõhust, mitte hääliku kestusest" (Ehala 1997: 62). 


\subsection{Eesti ortograafia nn põhireeglite problemaatilisus}

Eesti keele ortograafia reeglistamine on toimunud nii, et kerakujuline Maa (Ahrensi ortograafia) on tõlgendatud lapikuks, et siis lapiku Maa kaardid (kolme häälikuvälte määramine) uuesti sobitada kerakujulise Maa pildiga (Ahrensi ortograafiaga). Eesti ortograafia "teooria" (kui nii üldse on põhjust ütelda) lähtub sellest, et Ahrensi ortograafia ei ole kooskõlas eesti keele häälikusüsteemiga, sest Ahrens ei teadnud midagi eesti keele häälikute kolmest pikkuse järgust. Selle vea peavad parandama eesti ortograafia kaks põhireeglit. Kõigepealt tuleb igas Ahrensi ortograafias kirjutatud sõnavormis määrata iga hääliku välde - kas lühike, pikk või ülipikk - ning siis sellele määrangule vastavalt kirjutada, ja seejärel eesti ortograafia II põhireegli järgi parandada I põhireegli järgi kirjutatut, et kirjutatu sobiks Ahrensi ortograafiaga.

Kuna "Eesti keele käsiraamatus" on nn esimene põhireegel esitatud arusaamatus sõnastuses, siis on järgnevas mõlemad reeglid toodud klassikalisel kujul Johannes Valgma ja Nikolai Remmeli omal ajal palju kasutamist leidnud "Eesti keele grammatikast" (Valgma \& Remmel 1968: $\$ \$ 496,498$, lk 355-357). Johannes Valgma on need reeglid sõnastanud järgmiselt:

"I põhireegel. Lihthäälik kirjutatakse esimeses vältes ühe, teises ja kolmandas vältes kahe tähega [---]"

"II põhireegel. Häälikuühendeis (konsonantühendeis ja diftongides) kirjutatakse häälik ühe tähega [---]"

Õige kirjutamine eeldab niisiis järgmisi samme: 1) määrata kõigi häälikute välde - I, II, või III - ning kirjutada I-välteline hälik ühe ning II- ja III-välteline häälik kahe tähega; tuleb kindlaks määrata see, mille väljendamist Ahrens oma ortograafias ei ole taotlenud ega ole saanudki taotleda - hälikute välted; 2) esimene ortograafiareegel annaks tulemuseks Mihkel Veske häälikuväldete teoorias soovitatud ortograafia, näiteks nii: karrja, käiima, kiuusate, makksa jne; Ahrensi ortograafiasse jõudmiseks tuleb eesti ortograafia I põhireeglile lisada II põhireegel, mis 
võimaldab teisendused karrja, käiima, kiuusate, makksa > karja, käima, kiusate, maksa jne. Kõigepealt tuleb pimedas toas üles otsida kolmes eri suuruses mustad kassid, keda seal ei ole, ja seejärel osa neist toast välja ajada! Eesti ortograafia teise põhireegli tõttu oleme olukorras, kus kirjapilt newyorklane on igati korrektne, tallinnlane aga mitte! Ja eks kausjas, usjas, lipkond jts ole ka selle nn teise põhireegli sünnitatud ortograafiaebardid.

Eesti keele ortograafia nn põhireegleid poleks vaja, kui Ahrensi ortograafiat ei tõlgendataks kolme häälikuvälte valeteooria prisma läbi. Etteheidete tegemine Ahrensi ortograafiale algas kohe, kui eesti keeleteaduse lavale astusid eesti rahvuslikud keeleteadlased: Mihkel Veskest alates kuni kõige uuema ajani on kõlanud etteheited, et Ahrens pole mõistnud eesti häälikusüsteemi.

Kui raske on terve sajand kestnud kolme häälikuvälte sundideest vabaneda, selle illustratsiooniks võiks tuua palju näiteid, aga piisab eespool analüüsitud "Eesti keele käsiraamatust" (3 trükki!) ja akadeemilisest "Eesti keele grammatikast" I (1995) kui eesti keele hälikusüsteemi ja morfofonoloogia uurimise peavoolu tippudest. Päris tüüpiline on selline olukord: saadakse aru, et häälikuvälte aeg on läbi, aga vabaneda kolmest häälikuvältest ei suudeta. Mis siis veel rääkida igat masti skribarite õigekeelsuseeskirjade brošüüridest ja aabitsatest, mida kirjastajad üksteise võidu Eesti riigikeele õppimise-õpetamise turule toovad.

\subsection{Kolm (hääliku)väldet ei lahku rahvuslikust keeleteadusest}

Siiski, jää liigub. Aga aeglaselt. Akadeemiline hinnang on pigem äraootav kui selge seisukohavõtuga. Tartu Ülikooli teadlaste kõigiti korrektne ja väga suures mahus ainet hõlmav koondteos "Eesti keele hääldus" (EKH 2016) esitab eesti keele foneetika uurimise ajaloo ja hetkeseisu akadeemiliselt-objektivistlikult, justkui oleksid eesti keele häälikusüsteemi kirjeldamisel erinevad teooriad võrdväärsed. Autorid on hoidunud neile teooriatele selge hinnangu andmisest: näiteks peatükis 6.1.3 "19. sajandi teise poole kaks eesti keele häälduse kirjeldust" ei tõuse 
neutraalses sõnastuses kuidagi esile Wiedemanni ja Mihkel Veske teooriate antagonism just nimelt väldete käsitlemisel (EKH 2016: 198-201). Jakob Hurda puhul mainitakse tema prosoodiakäsitlust möödaminnes. Kogu teost läbib varjatult või varjamatult kolme sõnavälte ideoloogia, ehk teisiti öeldes, katse päästa kolme välte müüt või vaade või arusaam küll kõnetakti-, küll jalateooriaga, küll moorateooria erinevate variantidega, küll autoriteetidele (nt Ilse Lehiste) viidates.

Äsja ilmus "Keeles ja Kirjanduses" Külli Prillopi kaksikartikkel "Mida teeb moora eesti keeles?" (2018a: 245-364) ja "Varjatud muutused eesti keele prosoodilises struktuuris" (2018b: 433-452). Mõlemad väga mahukad artiklid on nende ajakirjanumbrite avaartikliteks.

Moorateooriaid on mitmesuguseid, aga Külli Prillopi moorateooriate osas väga erudeeritud artikkel on kahtlemata pühendatud eesti keele kolme välte mütoloogia kinnistamisele (Prillop 2018a: 346, 352$357 \mathrm{jm}$ ), selle erinevusega, et rõhuasetus ei ole kolmel häälikuvältel, vaid kolmel sõnavältel. Kuid kolme sõnavälte moorateooria esitatakse põhiliselt ikka samade lihthäälikukombinatsioonide varal, mida Leho Võrgust alates (Võrk 1966: 33-34; vrd ka Hinderling 1981: 98-99; Prillop Leho Võrku ei viita) üle poolesaja aasta on aegajalt kasutatud eesti "lihthäälikuväldete" kombinatsioonide illustreerimiseks: ude (I) - ute (II) - utte (III) - uude (II) - uute (II) - 'uude (III) - 'uute (III).

Prillopi kaksikartikli analüüs põrkab juba eos erinevate teadusideoloogiate kokkusobitamatusele: Prillopi analüüs ja moorateooria absolutiseerib eksperimenti ja mõõtmistulemusi (eeskujuks Ilse Lehiste); teistsuguses vaateviisis luuakse keele mudel pigem struktuurse analüüsi kui mõõtmistulemustega (ka Hint 2016). Näiteks geminaatidest kõneldes ütleb Prillop: "Häälduses on siiski tegemist ühe pika häälikuga, mitte identsete häälikute järjendiga” (Prillop 2018a:352). Ja teisal: “[---] geminaadid on pigem pikad häälikud ning hääldusorganid ei korda geminaatide häldamisel sama liigutust kaks korda, nagu peaks olema topeltkonsonandi puhul" (Prillop 2018a: 357-358; viide ka Pärtel Lippusele).

Strukturalist näeb asja teisiti. Geminaadid on struktuurselt paralleelsed $\mathrm{C}_{1} \mathrm{C}_{2}$-ga, nagu pikad vokaalid on struktuurselt paralleelsed 
diftongidega (viimast tunnustab nähtavasti Prillopki, vrd paati : paadi ja koitu: koidu kokkuarvamist).

Struktuurses tõlgenduses on mat $(t) i$, matsi ja masti silbistruktuuride maatriksis ühtmoodi kahesilbilised, kinnise esisilbiga ja obstruendiga 2. silbi alguses ning edasi-tagasi teisendatavad II- või III-vältelisteks. Enne eksperimenteerima ja mõõtma asumist peab olema arusaamine, et need silbitüübid on sarnased. Kui eesmärgiks on otsida põhjendusi, et üks neist eraldada mooradega manipuleerimiseks, siis eesti keele rõhusilpide II ja III välte erinevuse usutavat mudelit ei sünni. Ja keeleajalooliselt: nt muutus pitka > pikka ei too kaasa muutust silpide ehituses ega ka foneemide arvu vähenemist.

Samalaadne vahekord valitseb strukturalisti vaatekohast pikkade vokaalide ja diftongide vahel: variantide vaheldus suo ja soo ei muuda sõnavariandi foneemide arvu ega silbi fonoloogilist struktuuri; leiva > lèva /leeva/ ei muuda lahtise pika vokaalse silbituumaga silbi ehitust; pikkade vokaalfoneemide hüpotees muudaks selle (ja kõik sellelaadsed) varieerumised supletiivsuse (foneemiasenduse) juhtudeks, mis mingil kombel ei aita aru saada eesti keele morfoloogiast ja morfofonoloogiast.

Kust tuleb Külli Prillopi poolt aktsepteeritud piirang, mille kohaselt "vältida tuleks identsete segmentide järjendeid ühe morfeemi piires" (2018a: 361)? See piirang tuleb, nagu nüüd öeldakse - lambist - sellel ei ole ega saagi olla põhjendust. See on Prillopile vajalik, sest selle piirangu alusel saab geminaatsust tõlgendada mooraliseks. Prillop väidab, et enamik uurijaid on üksmeeles selles, et jalg on maksimaalselt kahesilbiline (2018a: 351). Mõned uurijad peavad võimalikuks ka kolmesilbilist jalga, aga kui enamusele apelleerida, siis on tõesti sedamoodi, et enamik eesti keele uurijaid on olnud sada aastat üksmeeles selles, et eesti keeles on - erinevalt teistest keeltest - häälikutel kolm väldet ja häälikuühenditel kaks väldet (hiljem on veidi väiksemal enamikul jätkunud üksmeelt ka selles, et eesti keeles on ka häälikuühendid oma väldetega foneemideks). Sellise enamusarvamusega ei ole eesti häälikusüsteemi uurijatel tänapäeval võimalik arvestada. 
Olgu Prillopi moorateooria graafiliselt kuitahes efektne, tema põhiideoloogiaks on ikka kolm hälikuväldet, kuigi seda otseselt ei öelda. Nagu kogu häälikuvälte teooria ajal nii on ka Prillopi puhul diagnostiliseks silbistruktuuride kolmik paati : paadi, koitu : koidu, konti : kondi. Kui ei mõisteta, et kõik need kolm silbitüüpi kuuluvad fonoloogias, morfofonoloogias, keeleajaloos (geminaatide astmevahelduse tekke seletuses) kokku, vaid esimest kaks (paati : paadi ja koitu : koidu) lahutatakse kolmandast (konti : kondi), siis ei ole lootustki aru saada, kuidas silbid funktsioneerivad eesti keele fonoloogilises ja morfofonoloogilises struktuuris ja kuidas need kolm silbitüüpi on keelejaloos omandanud ühesuguse astmevahelduse (vrd 2018b: 440).

Prillop nendib: "I väldet eristab II ja III vältest esisilbi struktuur" (2018a: 354). See peaks olema piisav põhjus, arvamaks nn I välte sõnad välja prosoodia analüüsist, kus tuleb eristada II ja III väldet: esisilbi struktuur ei ole samal analüüsitasandil. Aga ei. Kui eesmärgiks on eesti keele kolme vältusastme müüdi põhjendamine, siis tuleb ka esisilbi segmentaalne struktuur ning II ja III välte prosoodiline erinevus kokku sobitada. Olgu veel kord selgemast selgemini öeldud: nn I välde ei puutu II ja III välte eristamise seletamisel asjasse, sest I välte sõnade esisilbi segmentaalne struktuur ei ole samal tasandil II ja III välte prosoodilise erinevusega.

Prillopi teoorias on veel üks uuendus: ta liigitab eesti vältesüsteemi tulevikku prognoosides I välte sõnade esisilbi kergeks ning II ja III välte sõnade pika esisilbi raskeks (2018b: 434, 448). See lahutab Prillopi hüpoteetilise prognoosi Wiedemanni, Jakob Hurda, Valter Tauli, Robert T. Harmsi, Tiit-Rein Viitso (mõnes arenduses), Mati Hindi, Arvo Eegi, Martin Ehala jt eesti prosoodia tõlgendustest ning lükkab nn II ja nn III välte erinevuse tõlgendamise kerge ja raske rõhu, kerge ja terava rõhu, lauge ja terava aktsendi, tavalise rõhu ja ekstra rõhu, erilise silbikvantiteedi puudumise ja sellise kvantiteedi olemasolu (ja mis need terminid ongi) süsteemist täiesti uude dimensiooni: kui nii II kui ka III välte sõnad on raske esisilbiga (tegelikult on nad praegu lihtsalt pika esisilbiga), siis peab nende eristamiseks Külli Prillopi hüpoteesi kohaselt 
toimima mingi muu mehhanism. Selline keeletulevik ei ole võimatu, aga on praegu siiski veel ettearvamatu.

Külli Prillop ütleb, et erinevalt Alan Prince'ist (1980) lähtub tema tänapäevastest moorateooriatest (2018a: 354). Alan Prince’i analüüsile ei ole ette heita mitte midagi: ongi nii, et sõna on III vältes, kui rõhuline silp saab moodustada omaette jala, ning II välte korral peab jalas koos olema pikk rõhuline esilsilp ja rõhuta silp. See kehtib ka tänapäevastes moorateooriates (vrd Wiik 1986).

Kes söandaks ütelda, et Ilse Lehiste ei tundnud eesti keele häälikuajalugu ning eesti keele fonoloogiana esitatud teostes on temagi lähtunud kolmest hälikuvältest ning häälikuühendite väldetest (nt Lehiste 2000 [1977]). Fonoloogia osas tuleb sama tõdeda Paul Ariste puhul, kelle eesti keele fonoloogia skits ei kannata fonoloogiana kriitikat, sest see ei ole midagi muud kui kolme häälikuvälte ja liithäälikute kahe välte teooria ümberjutustus fonoloogia termineid kasutades (Ariste 1953: 100-107). Niinimetatud rahvusliku keeleteaduse häälikuõpetuse jaoks oleks tõehetk pidanud saabuma foneemiteooriaga. Foneemiteooria käsitab keelelist kommunikatsiooni kui diskreetsete häälikuliste etalonide (foneemide) kodeerimist füüsikalistesse signaalidesse, nende edastamist helilainetena ning vastuvõttu ja dekodeerimist samadesse diskreetsetesse kommunikatsiooniüksustesse (foneemidesse). Foneemiteooria(te) põhialused on universaalsed ning tänapäeval ei ole vähimatki võimalust kahelda selle teooria õigsuses: juba osatakse inimajus lokaliseerida piirkonnad, kus foneemide tunnuseid töödeldakse. Ka eesti keele fonoloogiat ei ole mõttekas käsitleda väljaspool üldteooriaid ja seoseid eesti keelele lähedaste fonoloogiliste süsteemidega.

\section{Kokkuvõte hääliku- ja silbivälte märkmisest eesti õigekeelsussõnaraamatutes (valikuliselt)}

Ahrensi uus kirjaviis soodustas moodsa eesti rahvuse tekkimist. Kõik katsed selle põhimõtteid revideerida on küündimatud ja vastutustundetud. Eesti keele kasutajale piisab, kui õigekeelsusallikates märgitakse 
tavaortograafiale lisaks silbi III väldet ja konsonantide palatalisatsiooni ning mõnel juhul ka silbipiiri (nt ÕS 2013 märgib III-vältelist silpi tähistades ka silbipiiri juhtudel nagu idi 'oom, aga ei võta seisukohta silbipiiri suhtes juhtudel nagu intuitiv' ism - kas soovitavam on intuiti-vism või intu-iti-vism).

Viimastel aastatel on moeasjaks saanud arutlused eestluse peatsest lõppemisest. Mõnedki rahvusliku identiteedi ja väärikuse sümbolid on kaotanud puutumatuse. Vabariigi Valitsuse residentsi nimetatakse balti aadliku nime järgi Stenbocki majaks, haldusreform õonestab eesti nimevara, eesti keele positsioon teaduskeelena on seatud küsitavaks. Nendes ise valitud defetismi ja enesehäbistamise oludes on kange usuvõitleja misjonigrammatik Eduard Ahrens oma ortograafia ja selge grammatilise mõtlemisega kindlalt eesti identiteedi eestseisjate poolel.

Eesti keele häälikusüsteemi, prosoodia ja astmevahelduse uurimiseks loodi piisavalt tugev alus juba 1875. aastaks: Faehlmann oli käsitlenud astmevaheldust tüvefleksiooni nähtusena, Ahrens lõi eesti hälikusüsteemile sobiva ortograafia, Jakob Hurt ja F. J. Wiedemann andsid seletuse eesti prosoodia olemusele, astmevaheldust käsitati morfoloogiasse kuuluva nähtusena. Need seisukohad on pärast saja-aastast vaheaega tänapäeval jälle muutumas eesti keele foneetika ja morfofonoloogia uurimise peasuunaks, kuigi ikka ja jälle tehakse katseid päästa midagi sellest "rahvuslikust keeleteadusest", mis opereerib kolme häälikuvälte, liht- ja liithäälikute ning sisehäälikutega.

Kompromissitu tagasipöördumine Faehlmanni ja Ahrensi ning Hurda ja Wiedemanni vaadete juurde aitaks mõista, kui asjatu on olnud erilise eesti keele teooria konstrueerimine, mis erineb üldkeeleteaduses tuntust ja tunnustatust. Kompromiss kerakujulise ja lameda Maa teooriate vahel ei ole võimalik. Eesti prosoodia uurimine on kahjuks paljuski kujunenud keeleteadlaste originaalitsemise võistluseks, milles tihti jäävad kaotajaks põhjendatud keeleteaduslikud vaated. Eesti keelt on esitatud tüüpilise toonikeelena, laest võetu põhjal on loetletud murrakuid, kus häälikutel ja silpidel on koguni neli vastanduvat pikkusastet, jpm. Kahjuks soodustab keeleteaduslike sensatsioonide esilekerkimist eesti 
keeleteaduse tugev institutsionaliseeritus: Tartu Ülikool, Eesti Keele Instituut ja ajakiri "Keel ja Kirjandus" on nii tugevad teaduskauba märgid, et nende siltide all publitseerimine tähendab juba iseenesest suurt edumaad riiklike teadusauhindadeni või peavooluteooria staatusse jõudmisel.

Praegune arutlus nendel teemadel ei ole esmakordne. EKG I (1995) ilmumise järel reageeris Kristiina Ross kriitikale (Hint 1997) kirjutisega "Eesti morfo(fono)loogia põnevamad probleemid: EKG contra Mati Hint" (Ross 1997). Tollest diskussiooniartiklist möödunud rohkem kui kahekümne aasta kestel ei ole kolme häälikuvälte teooria ja Ahrensi ortograafia kõverpeeglitõlgendus ilmutanud taandumise märke (vastupidistest deklaratsioonidest hoolimata). "Eesti keele käsiraamatu" 3. trükk (2007) kordas kümme aastat hiljem häälikuvälte seisukohti ja protseduure ning eesti ortograafia põhireegleid ikka samas arusaamatus sõnastuses, tegemata katsetki mõista Ahrensi ortograafiat või siis teoreetilisemal tasandil eristada häälikusüsteemi segmentaalset ja prosoodilist kihti. Kuidas saabki häälikuvälte teooria taanduda "rahvusliku keeleteaduse" ajalukku, kui kõigile teadlikele keelekasutajatele (eriti keeleõpetajatele) mõeldud tänapäevast keele uurimise seisu fikseerima-kajastama mõeldud koondteos ei suuda häälikuvälte teooriast vabaneda?

Just eesti ortograafia nn kaks põhireeglit ei võimalda lahti lasta kolme häälikuvälte valeteooriast. Kolme häälikuvälte määramine algab aabitsates ja jõuab maskeeritult kõige akadeemilisematesse grammatikatesse ja käsiraamatutesse veel palju aastaid, sest elamine keelemüüdis on mugavam ja harjumuspärasem kui püüdlemine vähem vastuolulise keelemudeli poole. Siiski on kolme häälikuvälte teooria aeg pääsmatult möödas, eesti aabitsate autoritel ja õigekirjametoodikutel tuleb Ahrensi ortograafia vabastada talle ülekohtuselt külge poogitud mõttetust ballastist. Eesti keeleteadus ei tohiks üheski uurimisvaldkonnas lubada endale peavooluvaadete kaitsmisel või propageerimisel vajumist korporatiivsesse ringkaitsesse, milles argumendiks muutub ka peavoolust erinevate seisukohtade avaldamisvõimaluste piiramine. 
Taustu tundes annab välte märkimine õigekeelsussõnaraamatutes üsna selge pildi parajasti valitsevast välteideoloogiast: kus märgitakse üksikhääliku, kus häälikuühendi ja kus silbi III väldet.

Kolme häälikuvälte teooria apogeeks võib pidada 1950-ndate lõppu ja 1960-ndate algust, kuigi just 1960-ndate esimesel poolel pöördusid vähemalt kolm keeleteadlast, erinevalt küll, aga siiski, tagasi Wiedemanni arusaamade poole: ameeriklane Robert T. Harms (1962), Eestis Tiit-Rein Viitso (1962), paguluses Valter Tauli (1965-1966).

Eesti keele õigekirjutuse-sõnaraamat 1918 (Eesti Kirjanduse Seltsi väljaanne) III väldet ei märgi. See on õigekirjutuse, mitte õigehäl̈lduse sõnaraamat.

Eesti õigekeelsuse-sõnaraamat 1925-1937 ilmus kolmes köites Eesti Kirjanduse Seltsi Keeletoimkonna toimetustena (toimetaja Joh. V. Veski; I köide 1925; II köide 1930; III köide 1937; I köite koostamisel abistas Joh. V. Veskit Elmar Muuk, II ja III köite koostamisel Helmut Pürkop; vt ÕSi lätted 2007: 9). Sõnaraamat märgib häälikuväldet, tõstes III-vältelise häliku või häälikuühendi esile poolpaksu kirjana: aas, $\boldsymbol{a} \boldsymbol{u}$, vaev, valla, aitama, ootama, kaikuma, kaotama, saatma, laast, kuusk, raat'sima, taatsi (tagurpidi), kaotsi, teiks (teie 'transl'), seik, mõistma, ápteek, kontsert ...

Sõnaraamatus analüüsitakse diftongis ülipikaks ainult diftongi järelkomponent; analüüsi vastuolulisust näitavad III välte määrangud taatsi ja raat'sima, teiks ja seik jpt süstemaatilised ebajärjekindlused; hilisdiftongide puhul on tendents analüüsida III-välteliseks hilisdiftongi järelkomponent ka geminaatklusiili ja obstruentse hälikuühendi ees (kaotama, kaotsi, vrd ootama, aitama; samasugust analüüsi esindab sõjajärgne TRÜ EKG I (1963: 100).

Väike õigekeelsus-sõnaraamat 1933 (koostanud Elmar Muuk. Tartu: Eesti Kirjanduse Seltsi Kirjastus) märgib õigekeelsussõnaraamatute ajaloos ajavahemikus 1918-1999 ainsana silbiväldet (ka kordustrükkides) ning on niimoodi otseses vastuolus Elmar Muugi enda koostatud eesti keele õpikutes esitatud häälikuvälte teooriaga: 'ap 'teek, 'kont'sert, 'kaotama, 'raat'sima, 'kohtu 'nik jne. Selline III-vältelise silbi märkimisviis on väga õnnestunud: pikk sõnavorm jagatakase III välte 
graavise märkidega kõnetaktideks enamasti just nii, nagu kõnetaktid realiseeruvadki.

Suur õigekeelsus-sõnaraamat 1948 (Eesti NSV Teaduste Akadeemia. Tartu: RK “Teaduslik Kirjandus”; ilmus kaks vihikut, kuni sõnani kobras) märgib kursiivkirjaga häälikuväldet "Eesti õigekeelsus-sõnaraamatu 1925-1937” eeskujul: apteek. Ülipikaks märgitakse diftongi teine

komponent: au, aur. "Kolmandavältelistes sõnades märgitakse ü l i p i k k h ä äl i k kursiivkirjaga: päev, kell, töötama, saama” (I vihik, lk 9).

Väike õigekeelsuse sõnaraamat 1953 (Eesti NSV Teaduste Akadeemia Keele ja Kirjanduse Instituut. Tallinn: Eesti Riiklik Kirjastus) on tegelikult Elmar Muugi VÕS-i (1933) stalinistlike lisandustega piraattrükk: 'ap'teek jne.

Õigekeelsuse sõnaraamat 1960 (Eesti NSV Teaduste Akadeemia Keele ja Kirjanduse Instituut. Toimetanud E[rnst] Nurm, E[rich] Raiet ja M[agnus] Kindlam. Tallinn: Eesti Riiklik Kirjastus) märgib häälikuväldet “Eesti õigekeelsuse-sõnaraamatu 1925-1937” järgi: a 'ptee 'k, kon 'tser 't, la 'ul ...; erinevuseks EÕS-ist (1925-1937) on kao 'tama-lao 'stama tüüpi silpides hilisdiftongi järel III-välteliseks analüüsida geminaatklusiil või obstruentse konsonantühendi esiliige, mitte hilisdiftongi jäelkomponent (vrd kaotama 1925. aasta EÕS-is ning teotama III-vältelise diftongi ja II-vältelise geminaatklusiiliga EKG I-s 1963: 100).

Õigekeelsuse sõnaraamat 1976 (Eesti NSV Teaduste Akadeemia Keele ja Kirjanduse Instituut. Toimetanud R[ein] Kull ja E[rich] Raiet. Tallinn: Valgus) jätkab häälikuvälte traditsiooni: $a^{\prime} p^{\prime} t e{ }^{\prime} k$ jne. Erinevalt varasematest häälikuvältele orienteeritud õigekeelsussõnaraamatutest arvatakse diftong III-välteliseks tervikuna, kuid mitte III-välteliseks analüüsitud III-vältelise klusiili või obstruentühendi ees: ' $a u$, aga $a u^{\prime} k$, au 'stama, hau 'kama; diftong silbituumana on võrdsustatud pika vokaaliga: vaa 'tama nagu vai 'kima ja laa 'stama nagu lao 'stama; algupäraste ja hilistekkeliste diftongide vahe on kaotatud.

Õigekeelsussõnaraamat 1980 (Eesti NSV Teaduste Akadeemia Keele ja Kirjanduse Instituut. Toimetanud R[ein] Kull ja E[rich] Raiet. Tallinn: Valgus) on kõiges olulises 1976. aasta sõnaraamatu kordustrükk. 
Eesti keele sõnaraamat ÕS 1999 (toimetanud Tiiu Erelt) märgib silbiväldet Elmar Muugi järgi, kuid tehniliselt Muugist erinevalt: .ap.teek. Diftongiga silbis on loobutud teise komponendi esiletõstmisest - diftong on III-vältelise silbi osa: .lauge, lauter jne.

Eesti õigekeelsussõnaraamat ÕS 2013 (toimetanud Maire Raadik): 80 aastat hiljem ollakse lõpuks peaaegu tagasi Elmar Muugi märkimisviisi juures, kuid siiski selle ebaoovitava erinevusega, et III välte graavisemärk ei eralda kõnetakte, vaid kirjutatakse vokaalse silbituuma ette: 'apt'eek; nii jääb mulje, et kõnetaktid on apt + eek, kuid see pole nii kõnetaktid on $a p+$ teek.

\section{Kirjandus}

Ahrens, Eduard 2003 [1853]. Grammatik der Ehstnischen Sprache Revalschen Dialektes. Erster Theil: Formenlehre. Eesti keeles: Eesti keele Tallinna murde grammatika. Esimene osa: Vormiõpetus. - Kristiina Ross (Toim.), Uue ajastu misjonilingvist. Eduard Ahrens 200. Tallinn: Eesti Keele Sihtasutus, 75-265.

Ariste, Paul 1953. Eesti keele foneetika. Tallinn: Eesti Riiklik Kirjastus.

Eek, Arvo 2008. Eesti keele foneetika. I. Tallinn: Tallinna Tehnikaülikooli Kirjastus. Ehala, Martin 1997. Eesti keele struktuur. Õpik güm[n]aasiumile. Künnimees.

EKG 1963 I = Eesti keele grammatika. I. Häälikuõpetus ja ortograafia. 1. vihik. Tartu: Tartu Riiklik Ülikool, eesti keele kateeder.

EKG I 1995 = Erelt, Mati, Reet Kasik, Helle Metslang, Henno Rajandi, Kristiina Ross, Henn Saari, Kaja Tael, Silvi Vare. Eesti keele grammatika I: Morfoloogia. Sõnamoodustus. Tallinn: Eesti Teaduste Akadeemia Eesti Keele Instituut.

EKH 2016 = Asu, Eeva-Liina, Pärtel Lippus, Karl Pajusalu, Pire Teras. Eesti keele hälldus. Eesti keele varamu II. Tartu: Tartu Ülikool.

EKK 2007 = Erelt, Mati, Tiiu Erelt, Kristiina Ross 2007. Eesti keele käsiraamat. Kolmas, täiendatud trükk. Tallinn: Eesti Keele Sihtasutus.

Erelt, Mati, Tiiu Erelt, Kristiina Ross 1997, 2000. Eesti keele käsiraamat. Tallinn: Eesti Keele Sihtasutus.

Faehlmann, Friedrich Reinhold 2002 [1843]. Ueber die Flexion des Wortstammes in der estnischen Sprache. - Verhandlungen der Gelehrten Estnischen Gesellschaft zu Dorpat. Ersten Bandes zweites Heft (I/2). Dorpat-Leipzig, 
15-26. Uustrükk: Kristi Metste (Koost.), Friedrich Robert Faehlmann. Teosed II, 37-49; eesti keeles: Sõnatüve fleksioonist eesti keeles, 50-60. Tartu: Eesti Kirjandusmuuseum.

Faehlmann, Friedrich Reinhold 1852. Ueber estnische Ortographie. - Verhandlungen der Gelehrten Estnischen Gesellschaft zu Dorpat. Band 2, Heft 4, Dorpat. - Uustrükk: Kristi Metste (Koost.), Friedrich Robert Faehlmann. Teosed II, 221-244; eesti keeles; Eesti ortograafiast, 245-264. Tartu: Eesti Kirjandusmuuseum.

Grammatika 1958 = Грамматика финского языка. Академия Наук СССР. Карельский филиал. Институт языка, литературы и истории. Москва-Ленинград: Издвтельство Академии Наук СССР.

[Grenzstein, Ado] Piirikivi 1876. Eesti õigestkirjutuse parandajatele. - Eesti Postimees 50-52; 15., 22. ja 29. XII 1876. - Uustrükk: Simo Runnel (Koost.), Ado Grenzstein: Eesti haridus. Eesti mõttelugu 106. Tartu: Ilmamaa, 308334.

Harms, Robert T. 1962. Estonian Grammar. Uralic and Altaic Series 12. Bloomington: Indiana University Publications; Hague: Mouton.

Help, Toomas 1988. Eesti ja soome keele suhted: Wiedemann Ahrensi ja Veske vastu. - Keel ja Kirjandus 4, 198-207.

Help, Toomas 1989. Akadeemik F. J. Wiedemann eesti ja soome keele erinevuste rõhutajana. - Seppo Suhonen (Toim.), Ferdinand Johann Wiedemannin muisto. Castrenianumin toimitteita 31. Helsinki: Helsingin yliopisto, 15-30.

Hermann, Karl August 2001 [1884]. Eesti keele Grammatik. Koolide ja iseõppimise tarvis Tartu. - Uustrükk: Urmas Sutrop (Koost.), Esimesest algusest meie ajani. Karl August Hermann 150. Tallinn: Eesti Keele Sihtasutus, 25-140.

Herman, Karl August 2001 [1900-1903]. Ahrens, Eduard. - Eesti üleüldise teaduse raamat, Tartu, 1900-1903, 179-181. Uustrükk: Urmas Sutrop (Koost.), Esimesest algusest meie ajani. Karl August Hermann 150. Tallinn: Eesti Keele Sihtasutus, 208-211.

Hinderling, Robert 1981. Die deutsch-estnischen Lehnwortbeziehungen im Rahmen einer europäischen Lehnwortgeographie. Wiesbaden: Otto Harrassowitz.

Hint, Mati 1971. Licentia poetica sõnarõhu valdkonnas. - Looming 10, 1567-1578.

Hint, Mati 1983. Eesti keele õpik IX klassile. Tallinn: Valgus.

Hint, Mati 1997. Eesti foneetika möödunud hiilgus ja möödumatu viletsus. - Keel ja Kirjandus 2, 73-82; 3, 157-164. 
AHRENSI ÕLGADEL

Hint, Mati 2002. Eesti ortograafia (silbi)fonoloogiline põhi. - Keel ja Kirjandus 1, 17-25.

Hint, Mati 2013. Ado Grenzsteini jälg häälikuvälte teooria eduloos ja eksitustes. Keel ja Kirjandus 11, 842-850.

Hint, Mati 2016. Mõõtmised ei loo teooriat. - Keel ja Kirjandus 8-9, 627-637.

Hurt, Jakob 2012 [1864]. Lühikene õpetus õigest kirjutamisest parandatud viisi. Tartu: Õpetatud Eesti Selts. - Uustrükk: Jaak Peebo, Hando Runnel (Koost.), Jakob Hurt. Keelemees. Eesti mõttelugu 107. Tartu: Ilmamaa, 213-228.

Jänes, Henno 1966. Eesti keel. Selle ehitus, areng ja ortoloogia. San Francisco: Eesti Kirjanduse Komitee.

Karlsson, Fred 1982. Suomen kielen äänne- ja muotorakenne. Porvoo, Helsinki, Juva: Werner Söderström Osakeyhtiö.

Kask, Arnold 1958. Võitlus vana ja uue kirjaviisi vahel XIX sajandi eesti kirjakeeles. Eesti NSV Teaduste Akadeemia Emakeele Seltsi Toimetised 2. Tallinn: Eesti Riiklik Kirjastus.

Kettunen, Lauri 1916. Viron ja suomen eroavuudet. Äännehistoriallisia selvittelyjä harjoituskappaleineen. Jyväskylä: Gummerus.

Lehiste, Ilse 2000 [1977]. Quantity in Estonian language and poetry. - Journal of Baltic Studies 8 (2), 130-141; eesti keeles: Välde eesti keeles ja luules. - Jaan Ross (Koost.), Ilse Lehiste: Keel kirjanduses. Eesti mõttelugu 36. Tartu: Ilmamaa, Tartu 176-190.

Loorits, Oskar 1923. Eesti keele grammatika. Tartu: Odamees.

Must, Mari 1987. Kirderannikumurre. Häälikuline ja grammatiline ülevaade. Eesti NSV Teaduste Akadeemia Keele ja Kirjanduse Instituut. Tallinn: Valgus.

Muuk, Elmar 1925. Kolmanda välte märkimisest kirjas. - Eesti Keel 5-6, 123-130.

Muuk, Elmar 1927. Eesti keeleõpetus. I. Hääliku- ja vormiõpetus. Akadeemilise Emakeele Seltsi toimetised XII. Tartu: Eesti Kirjanduse Seltsi Kirjastus.

Muuk, Elmar 1936. Lühike eesti keeleõpetus. I. Hääliku- ja vormiõpetus. Seitsmes trükk. Tartu: Eesti Kirjanduse Seltsi Kirjastus.

Muuk, Elmar, Karl Mihkla 1936. Eesti keskkooli-grammatika ühes harjutustikuga. II. Häälikuõpetus. Neljas, täiendatud trükk. Tartu: Eesti Kirjanduse Selts.

Muuk, Elmar, Karl Mihkla 1938. Eesti keskkooli-grammatika ühes harjutustikuga. III. Vormiõpetus. Teine, täiendatud trükk. Tartu: Eesti Kirjanduse Selts.

Palmeos, Paula 1963. Soome keele õpik. Lugemik, grammatika, sõnastik. Tallinn: Eesti Riiklik Kirjastus, Tallinn.

Prillop, Külli 2018a. Mida teeb moora eesti keeles? - Keel ja Kirjandus 5, 245-364. 
Prillop, Külli 2018b. Muutused eesti keele prosoodilises struktuuris. - Keel ja Kirjandus 6, 433-452.

Prince, Alan 1980. A metrical theory of Estonian quantity. - Linguistic Inquiry 11 (3), 511-562.

Põldmäe, Rudolf 1988. Noor Jakob Hurt. Tallinn: Eesti Raamat.

Remes, Hannu 1982. Viron kielioppi. Porvoo, Helsinki, Juva: Werner Söderström Osakeyhtiö.

Ross, Kristiina 1997. Eesti morfo(fono)loogia põnevamad probleemid: EKG contra Mati Hint. - Keel ja Kirjandus 5, 298-304.

Ross, Kristiina 2003. Viimane misjonilingvist Eduard Ahrens eesti kirjakeele reformijana. - Keel ja Kirjandus 5, 321-330.

Tauli, Valter 1966. On Quantity and Stress in Estonian. - Acta Linguistica Hafniensia IX (2), 144-162.

Tauli, Valter 1972. Eesti grammatika I. Hääliku-, vormi- ja sõnaõpetus. Upsala: Soome-Ugri Keelte Instituut.

Valgma, Johannes, Nikolai Remmel 1968. Eesti keele grammatika. Käsiraamat. Tallinn: Kirjastus "Valgus".

Valmet, Aino, Ellen Uuspõld, Ellen Turu 1981. Учебник эстонского языка. Eesti keele õpik. Tallinn: Valgus.

Velliste, Trivimi 1978. Selges eesti keeles. Ameerika professori usutlus. - Sirp ja Vasar 26, 30.6.

Viitso, Tiit-Rein 1962. Tüvelisest astmevaheldusest (eriti eesti keeles). - Emakeele Seltsi aastaraamat VIII (1962). Tallinn: Eesti Riiklik Kirjastus, 44-62.

Võrk, Leho 1966. Viron kielen ääntämys. Studia Philologica Jyväskyläensia II. Jyväskylä: Jyväskylän yliopisto.

Vääri, Eduard 1980. Eesti keele õpik keskkoolile. 10. trükk. Tallinn: Valgus.

Wiedemann, Ferdinand Johann 2011 [1875]. Grammatik der ehstnischen Sprache zunächst wie sie in Mittelehstland gesprochen wird, mit Berücksichtigung der anderen Dialekte. St.-Pétersbourg; eesti keeles: Eesti keele grammatika. Tallinn: Eesti Teaduste Akadeemia Emakeele Selts.

Wiik, Kalevi 1986. Viron toinen ja kolmas kvantiteetti kielen oppijan kannalta. Turun yliopiston suomalaisen ja yleisen kielitieteen laitoksen julkaisuja 27. Turku: Turun yliopisto.

Wiik, Kalevi 1991. Viron monikon partitiivi suomalaisen oppijan kannalta. Turku: Turun yliopisto, fonetiikka.

ÕSi lätted. Õigekeelsussõnaraamatud läbi sajandi. Eesti keele õigekirjutussõnaraamat 1918. Urmas Sutrop (Koost.). Tallinn: Eesti Keele Instituut, Eesti Keele Sihtasutus, 2007. 


\title{
On the shoulders of Ahrens. The orthography by Eduard Ahrens in the past and nowadays
}

\author{
MATI HINT \\ Tallinn University
}

In his grammars of Estonian (1843 and 1853), Eduard Ahrens (1803-1863), the pastor of Kuusalu, created a new orthography for the Estonian language. Ahrens intended to more adequately render the structure of short and long syllables in Estonian. Finnish orthography served as a model for Ahrens, thanks to the many similarities between the phonetic and morphophonemic (grade alternation) systems of both languages. The most important difference between the phonetic systems of Finnish and Estonian is in the prosody of Estonian: it is possible to pronounce long stressed syllables with two distinctive syllable quantities (traditionally called the second and the third degree of quantity) without any change in the segmental structure of the syllable. This extra prosodic means of Estonian was not rendered in the orthography proposal made by Ahrens, because he concentrated on the segmental structure of syllables. This was a prescient decision, as it provided the new orthography with stability, and due to it this orthography has served the Estonian nation and the Estonian culture well since the 1870 s.

In the years 1840-1875 the foundations for the investigation of Estonian in accordance with the principles and theories of general linguistics were created (Fr. R. Faehlmann, Eduard Ahrens, Jakob Hurt, F. J. Wiedemann). Unfortunately, in the 1870-1880s a new theory of Estonian phonetics was formed (in 1879 Mihkel Veske created an original theory of the Estonian sound system; in 1884 Karl August Hermann used this new theory in his popular grammar of Estonian). In this theory the prosodic quantity of long syllables was interpreted as the quantity degrees of segmental sounds: both vowels and consonants were described as having three distinctive degrees of length (short, long, and overlong), and diphthongs and consonant clusters as having two distinctive degrees of length (long and overlong). The phonetic system of Estonian was looked at as totally different from any other phonetic system. Ahrens's orthography 
was reinterpreted in a way that required any sound in a stressed syllable to be determined to have one of three quantity degrees (short, long, overlong), and the diphthongs and consonant clusters to have long or overlong quantity. This view dominated in Estonian linguistics without any real opposition for about a hundred years (1880s-1980s). The theory of three quantity degrees is totally incompatible with any phonemic theory. Despite it, up to now, the methods and rules for learning orthography are based on the false assumption that Ahrens's orthography should be complemented with decisions about the quantity degree of any vowel or consonant or of so-called compound sound. This makes the rules for orthography schizophrenic, for in order to achieve the orthography as it is, a series of unnecessary steps must be taken.

However, from the 1960s to the present day, the theory of three quantity degrees has lost ground step by step, and the views of Jakob Hurt and F. J. Wiedemann have made their way back to scientific discussion. In scientific discussion of Estonian phonetics and phonology, and in orthographic dictionaries, the theory of three quantity degrees in declarations has been abandoned, but in practice (A-B-C books, popular overviews of Estonian phonetics, the methods for teaching and learning orthography, some phonological interpretations) the treatment of Estonian as a language with a very peculiar phonological quantity system is still active.

However, the ice is breaking.

Keywords: phonetic systems; theory of ternary quantity system of vowels and consonants; prosodic syllable quantity; orthography; grade alternation; Finnish; Estonian

\section{Mati Hint}

Tallinna Ülikooli humanitaarteaduste instituut

Narva mnt 29

10120 Tallinn, Estonia 